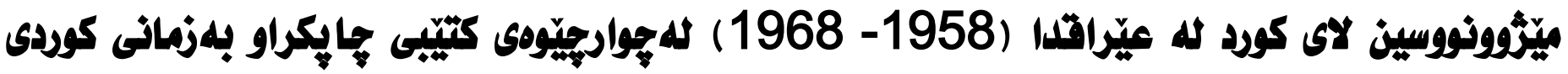

\section{بلمشار عمر رِفيق}

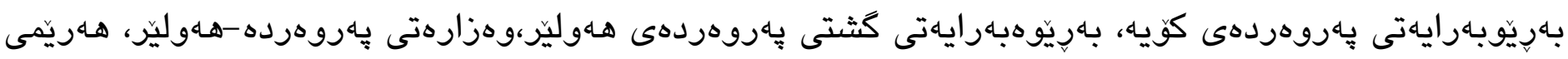

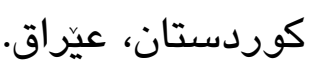

ئيمهيل: gashdarumar80@gmail.com

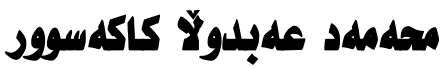

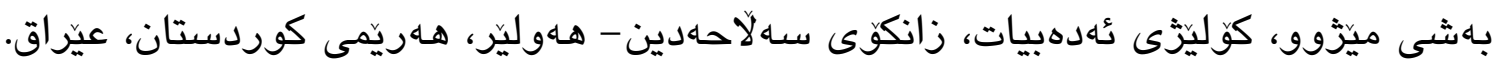
makakasur@yahoo.com : ئيمهيل

ويوخته:

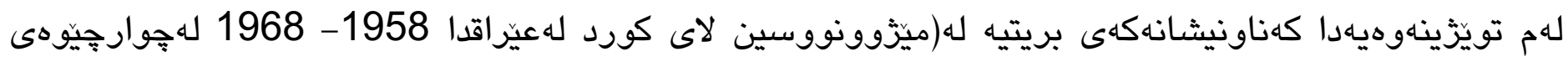

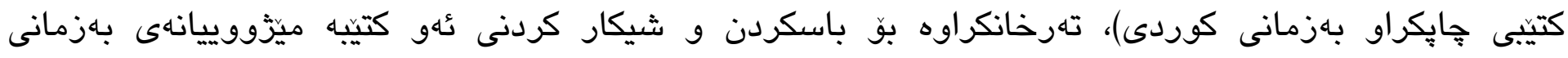

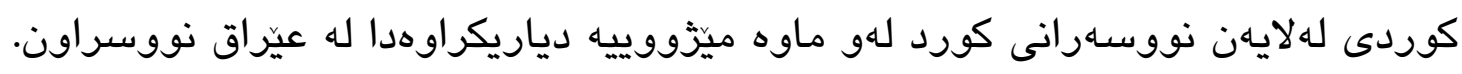

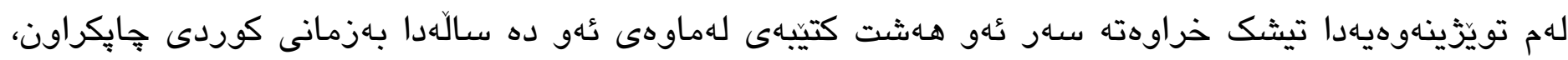

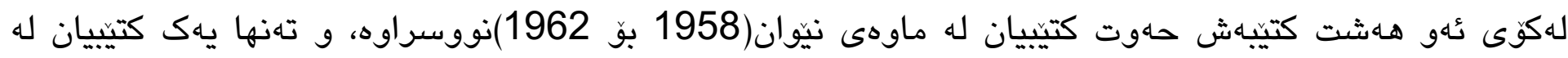

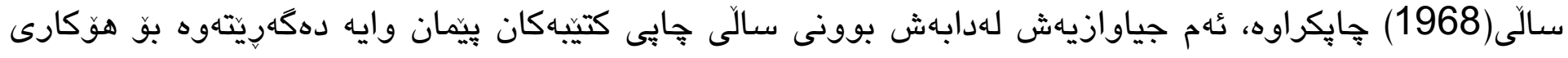

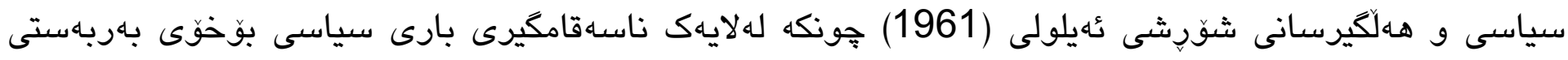

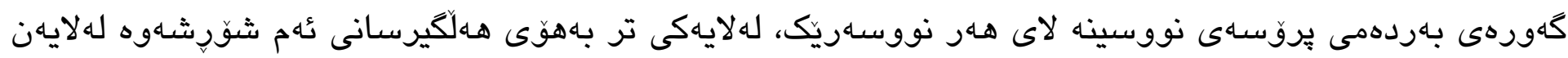

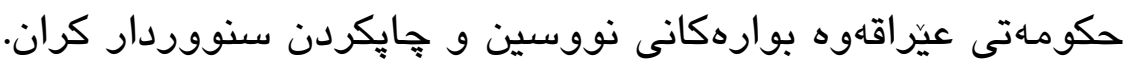

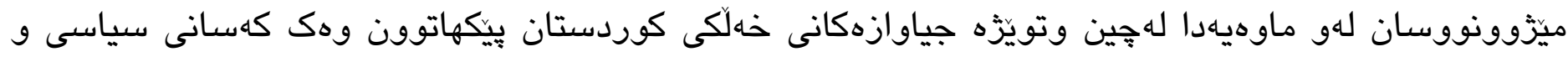

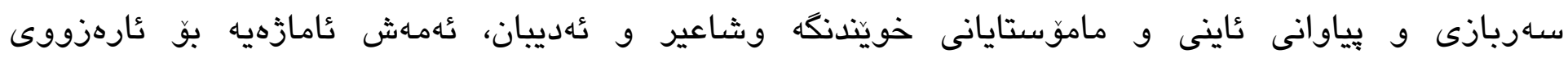

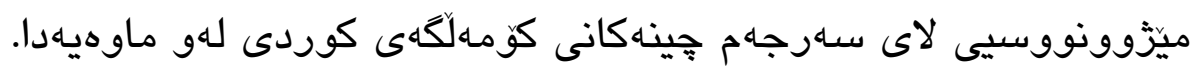

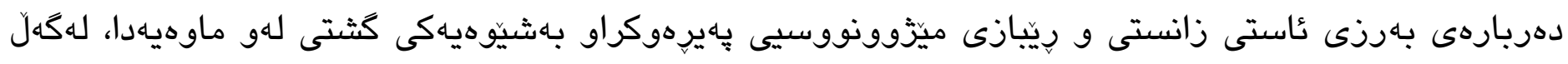

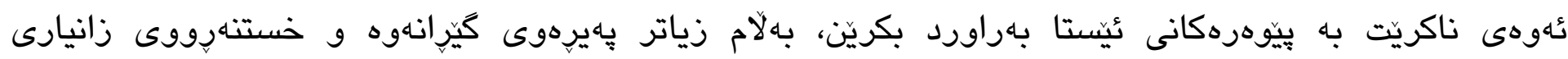




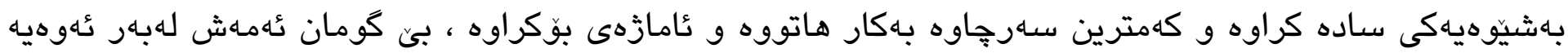

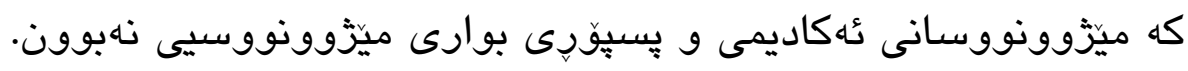

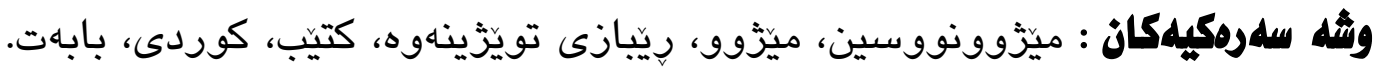

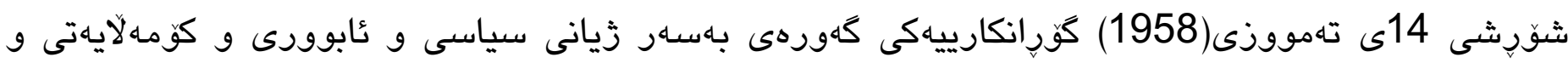

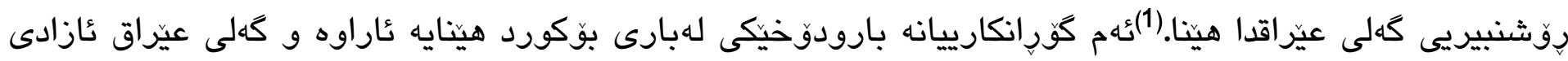

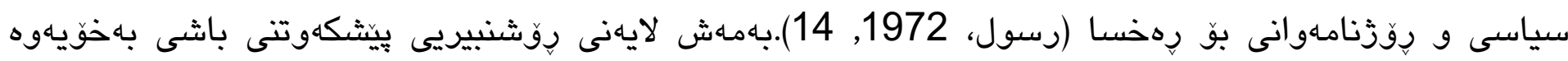

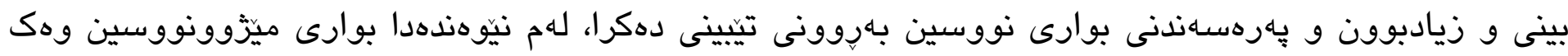

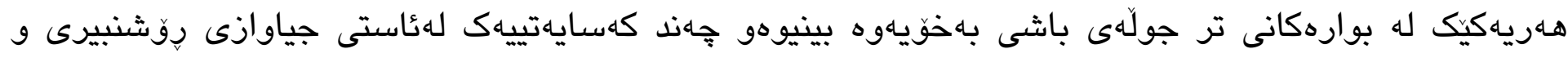

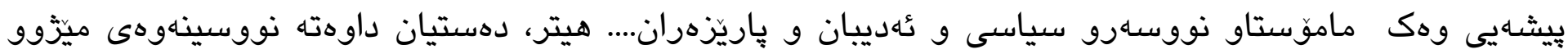

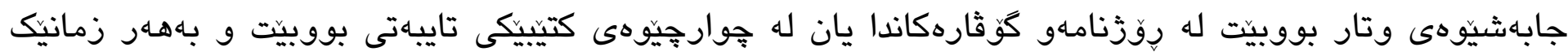

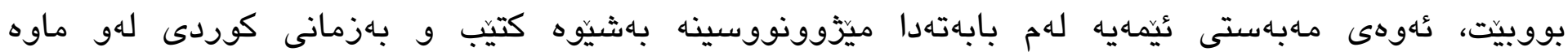
دياريكراوهدا.

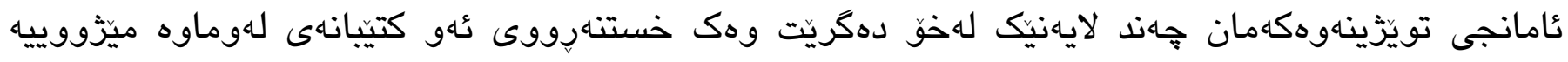

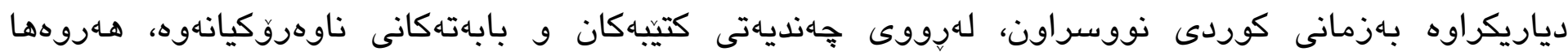

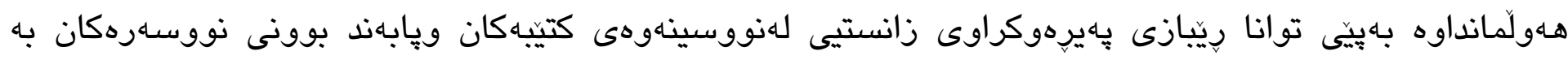

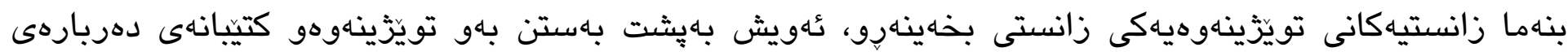

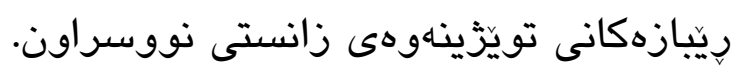

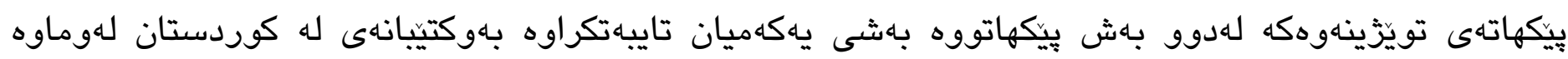

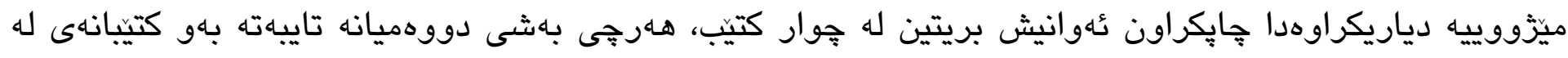

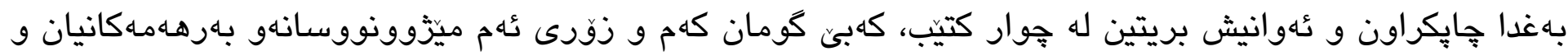

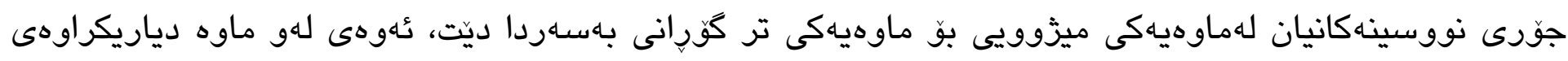

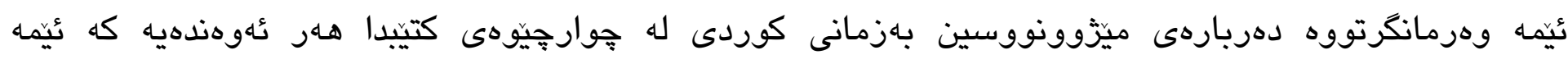

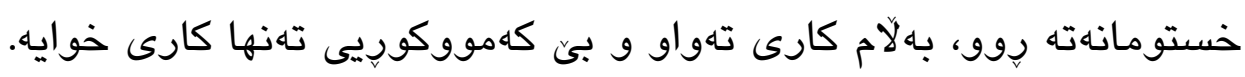

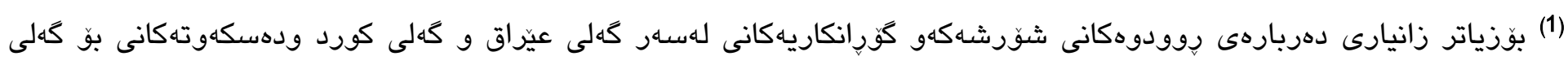

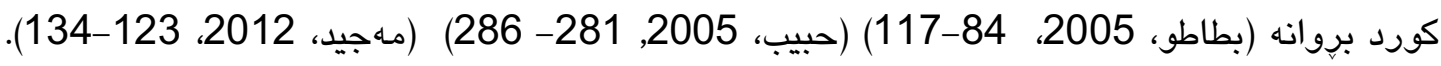




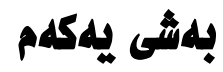

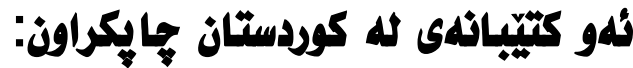

\section{يدكdم/ هaمزيه عdبلدولآ(1):}

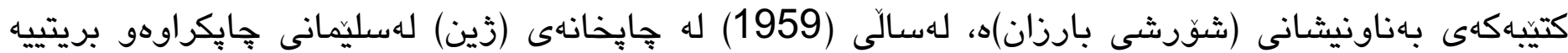

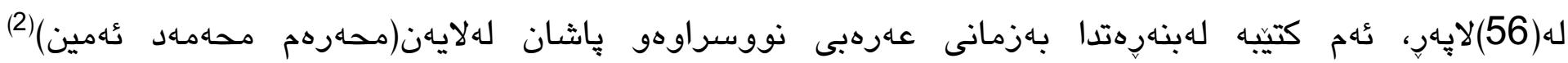

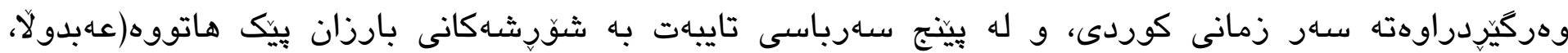

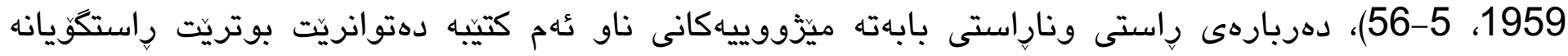

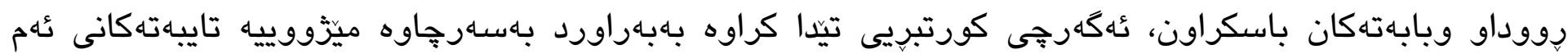

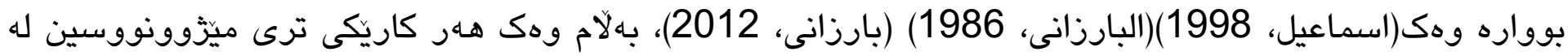
تينيينيكان بهدهر نييه وهك دواتر دهيانخهينه

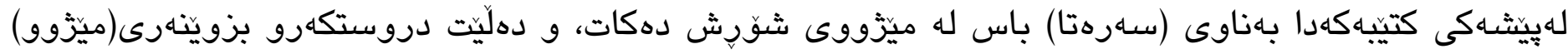

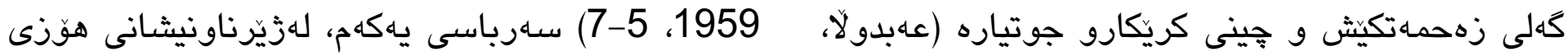

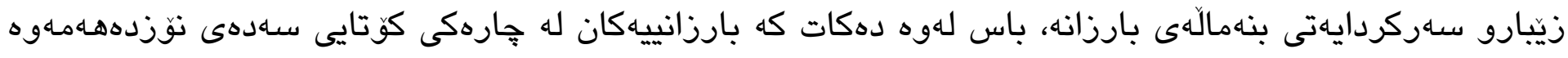

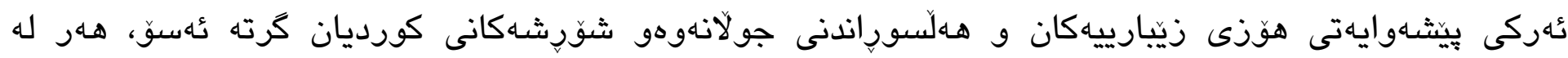

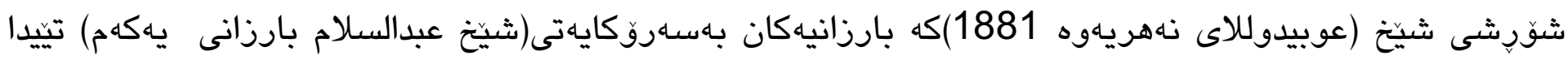

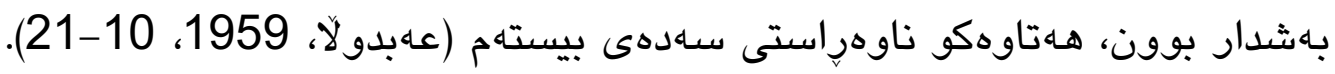

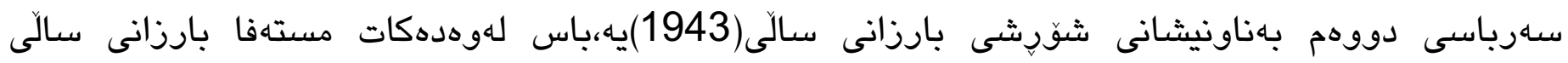

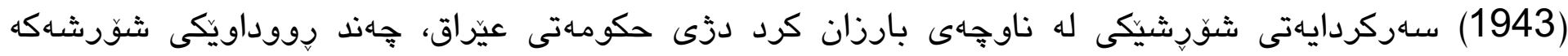

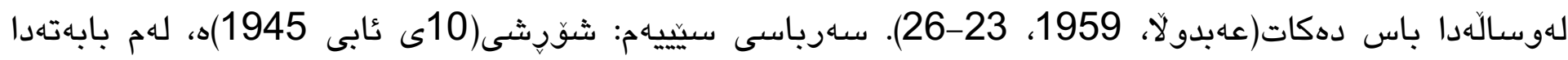

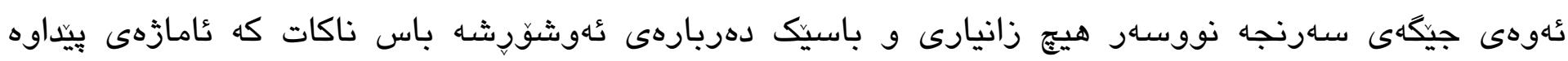

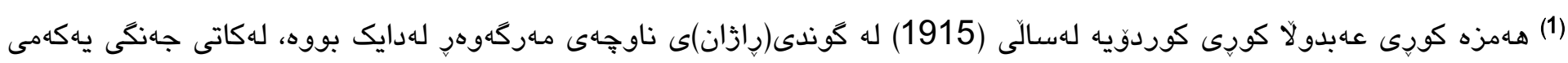

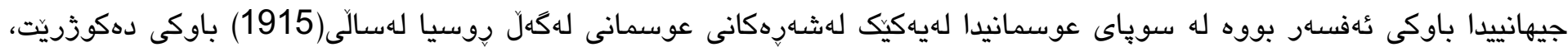

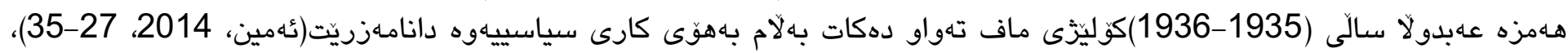

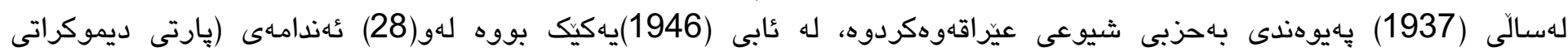

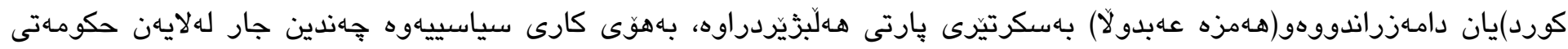

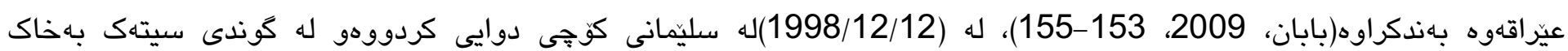

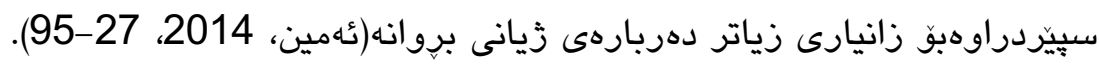

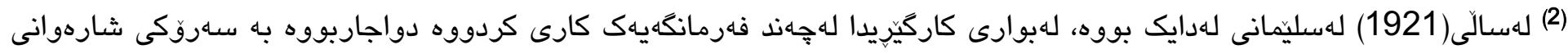

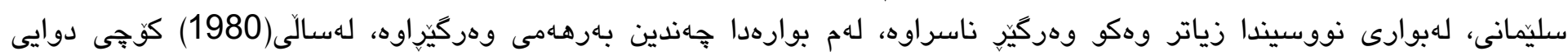
كردووه (بابان، 2006، 657). 


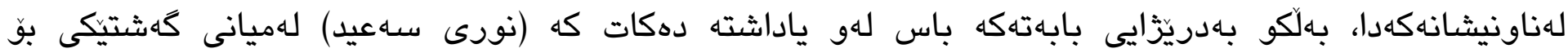

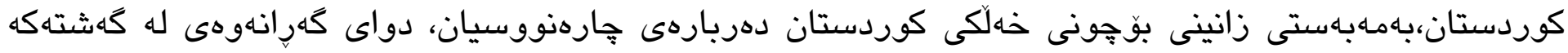

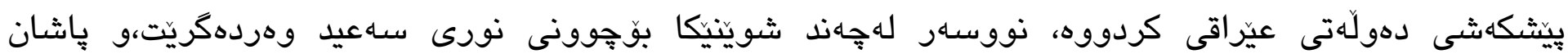

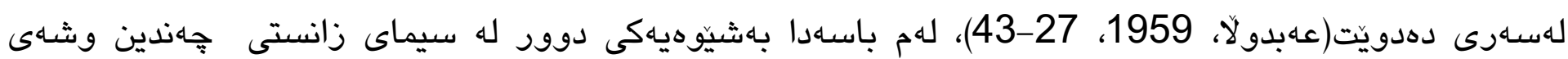

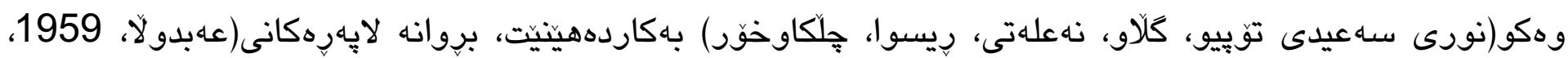

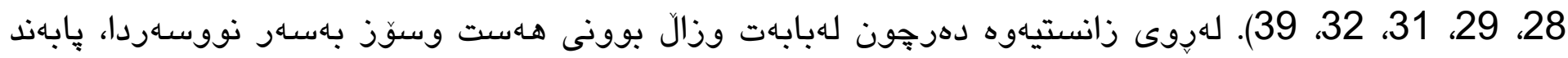

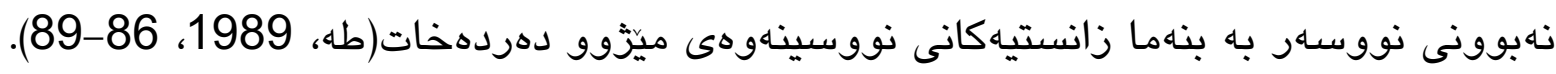

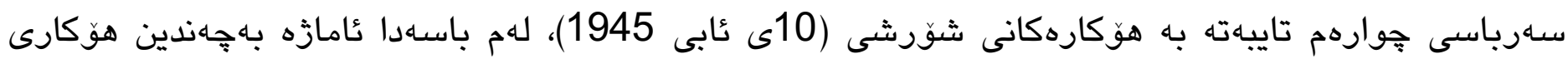

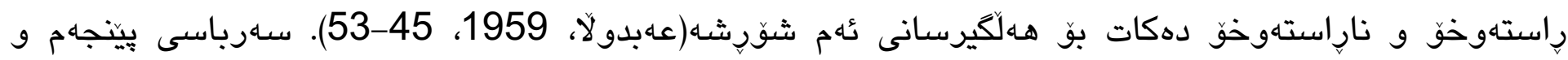

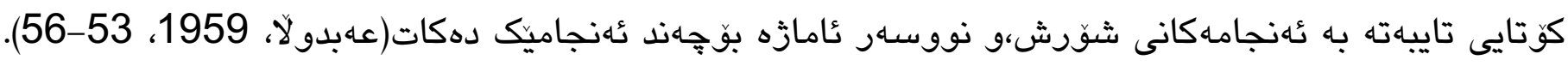

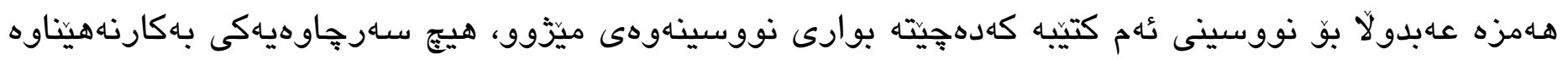

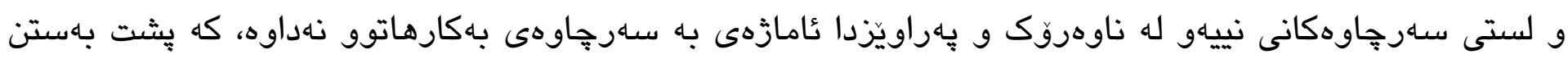

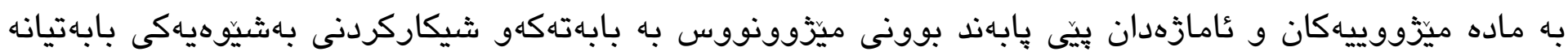

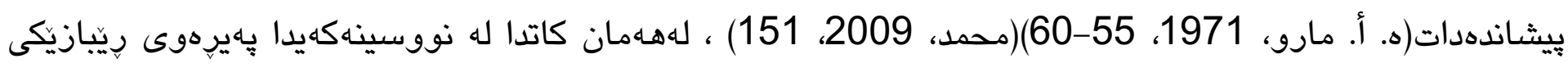

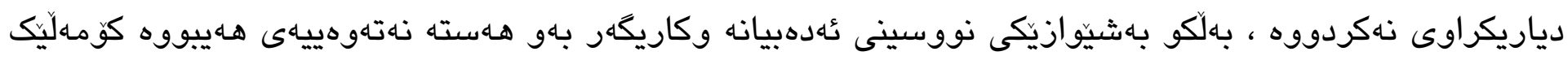

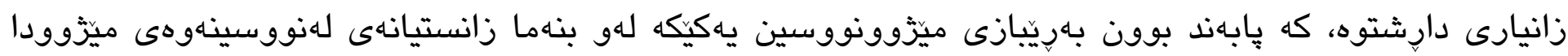

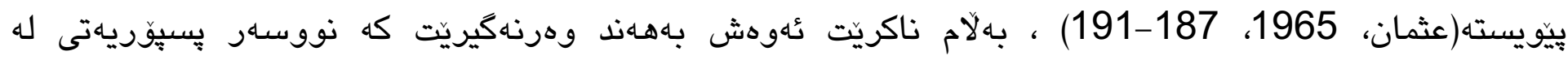

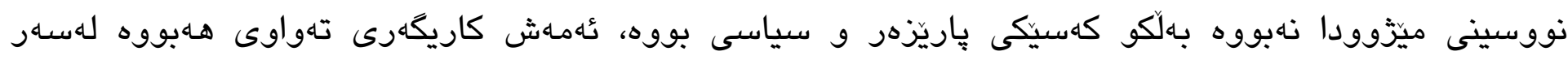

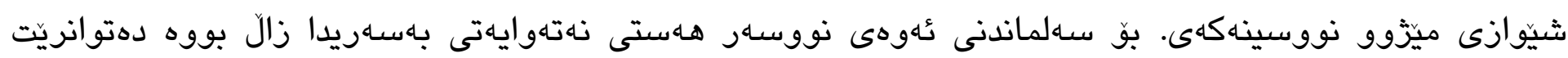

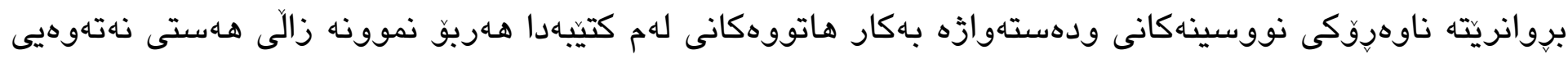

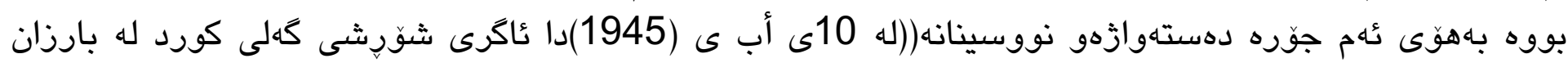

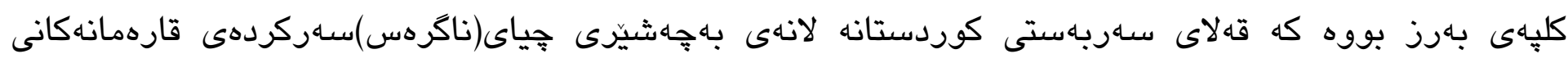

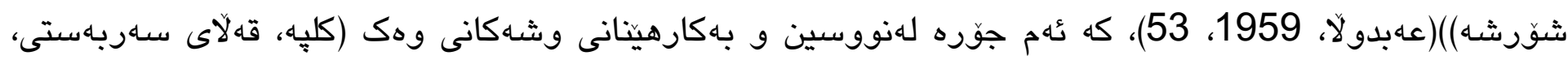

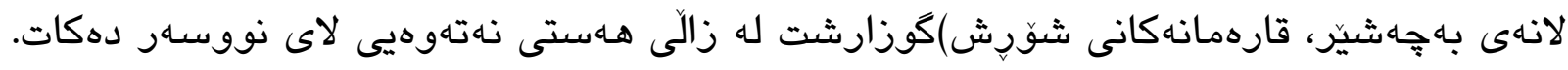

\section{دوومم/ صالح قلهمتان(1):}

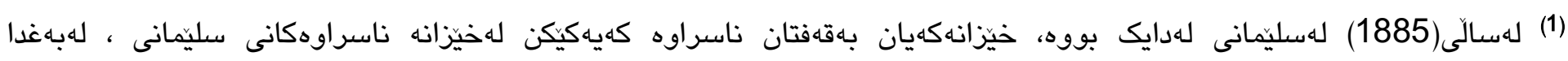

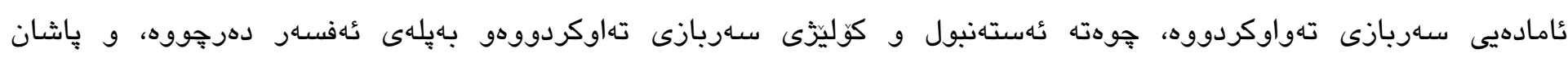

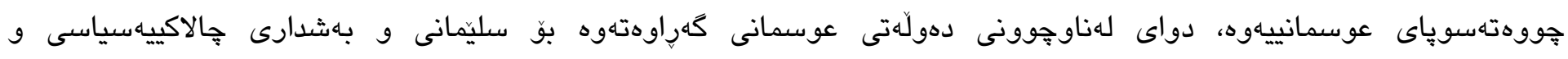

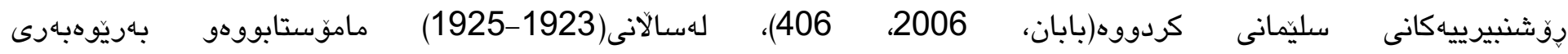

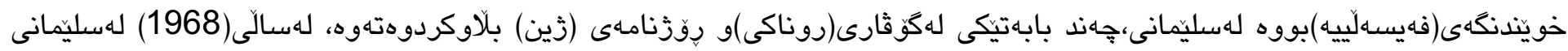

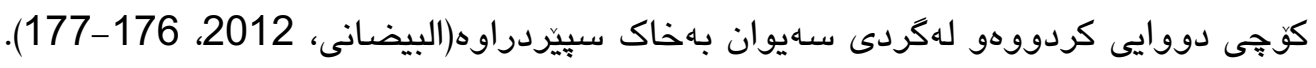




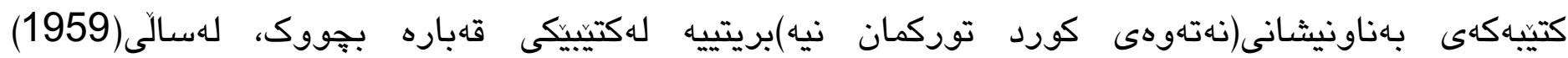

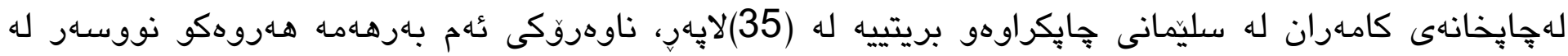

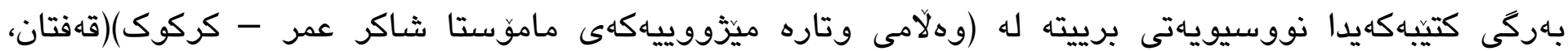

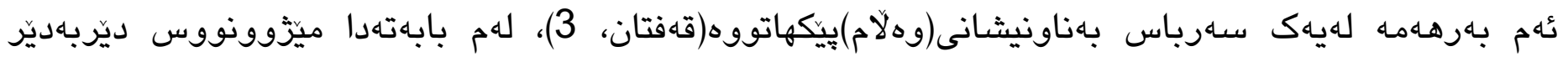

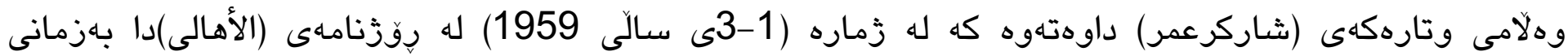

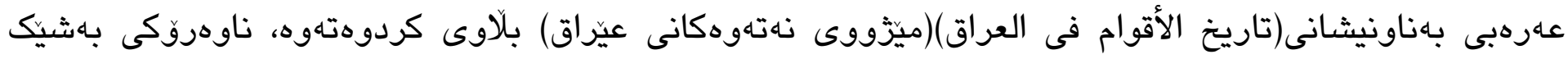

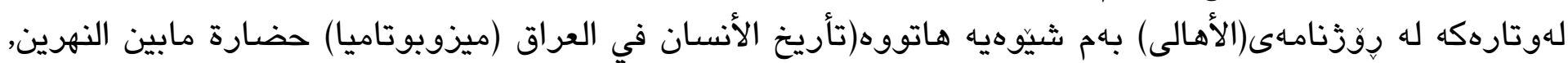

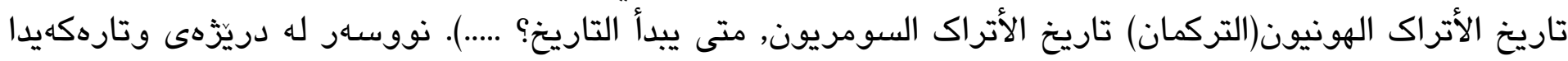

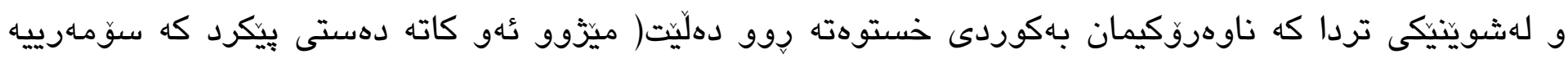

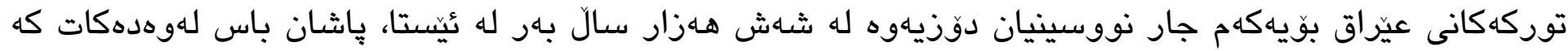

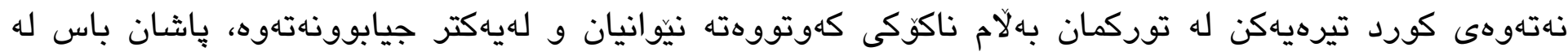

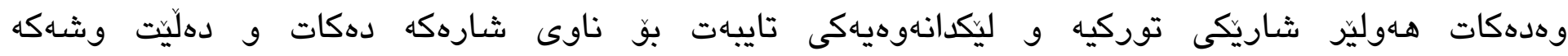
توركيه.....(عمر، 1959، 195

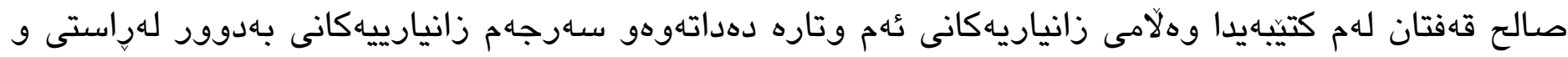

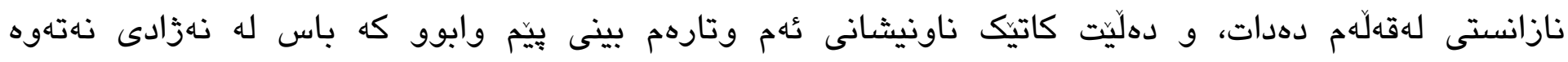

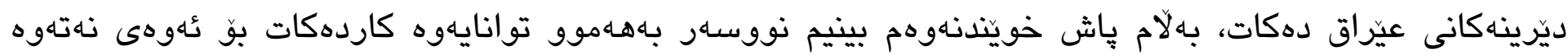

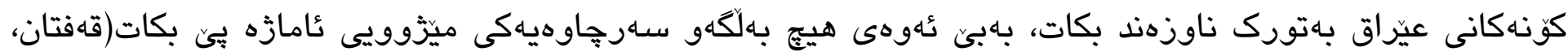

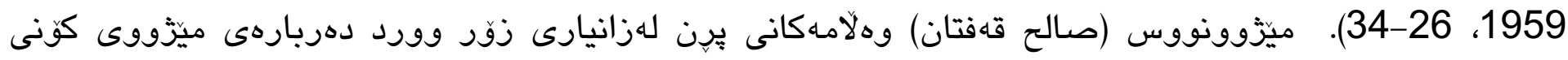

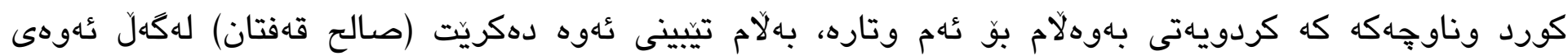

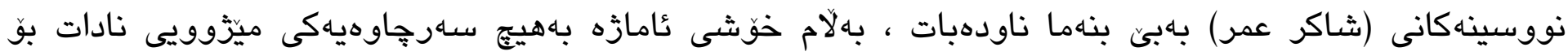

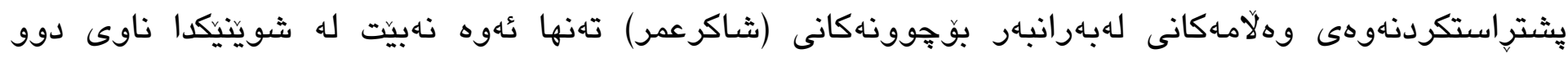

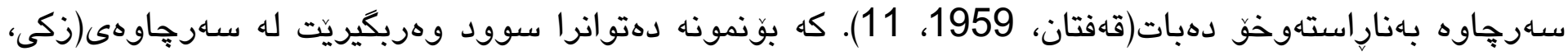

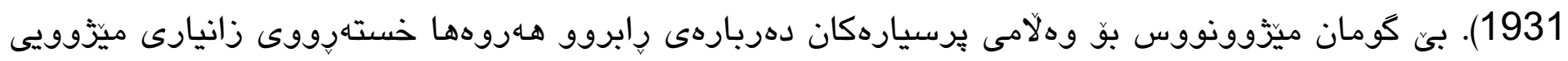

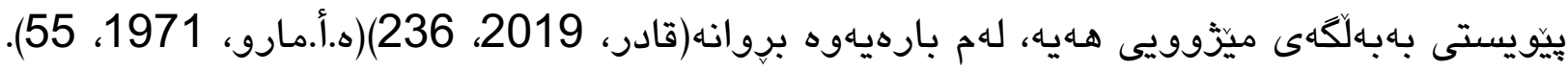

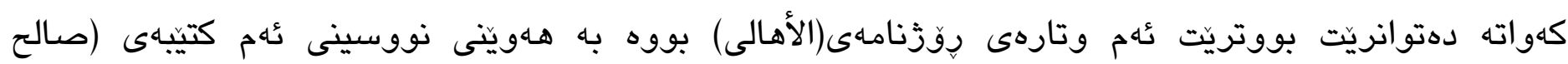

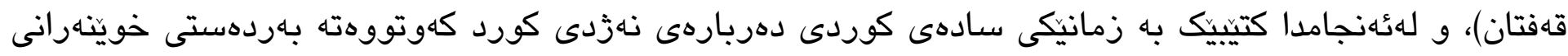

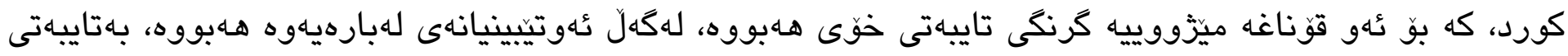

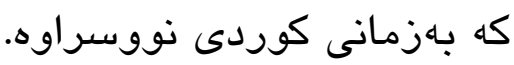




\section{سينيلم// كاكلى ريّبوار(1):}

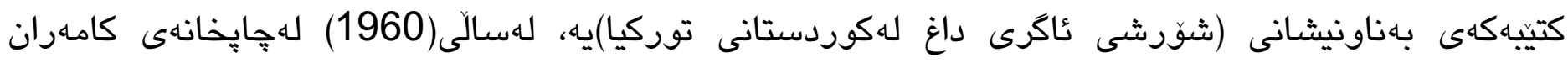

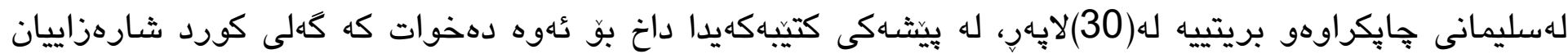

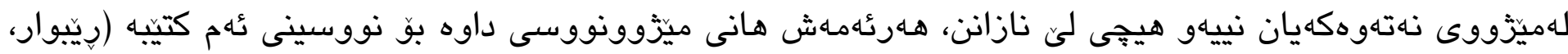

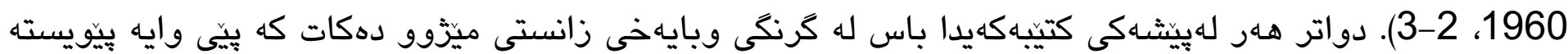

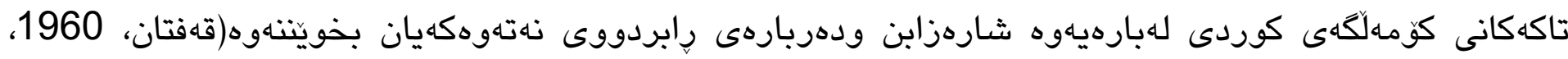

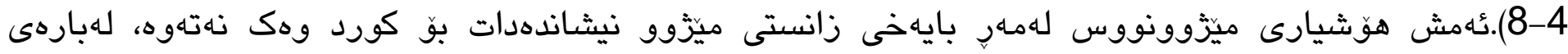

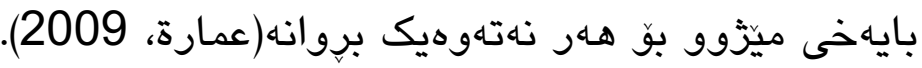

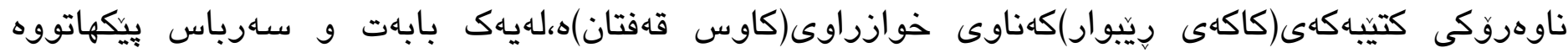

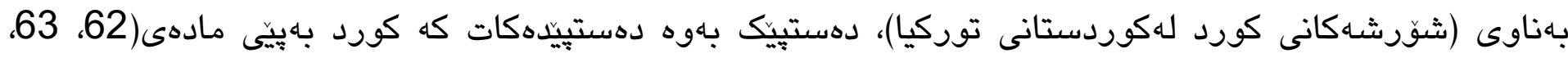

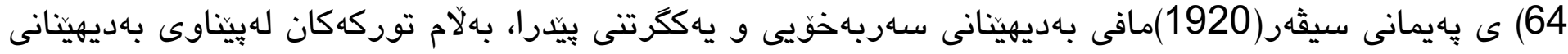

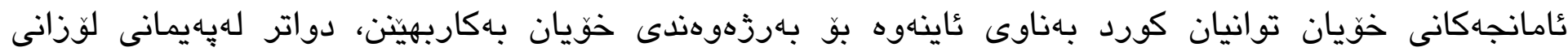

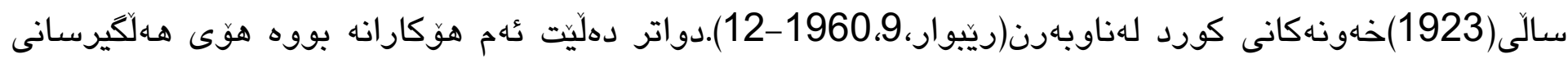

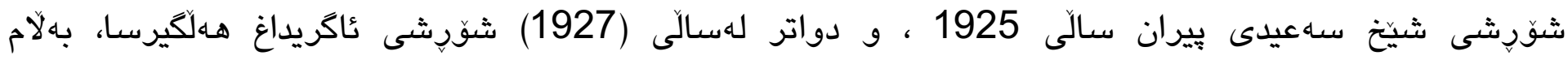

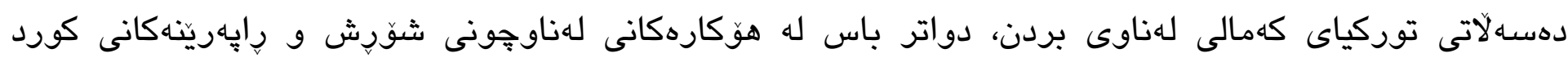

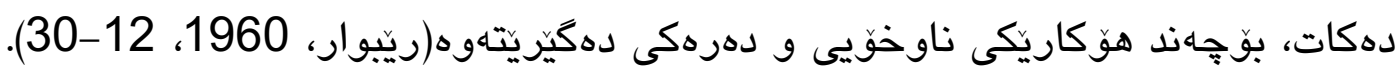

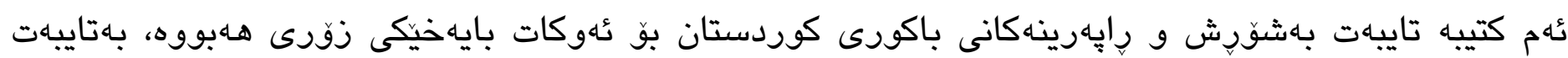

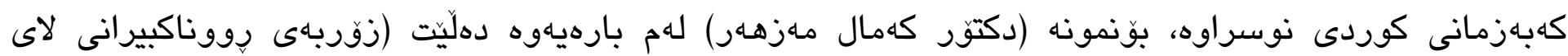

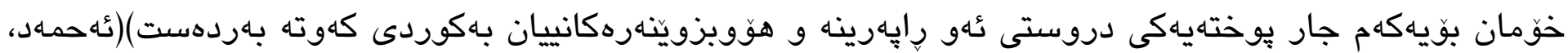

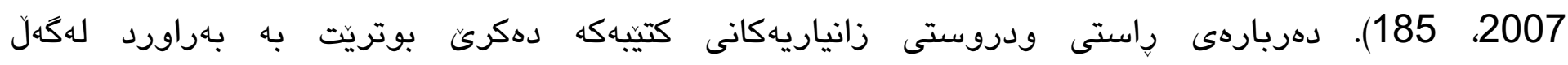

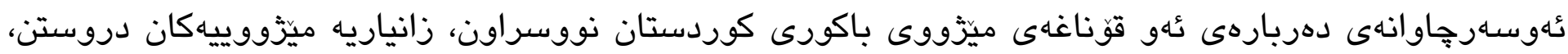

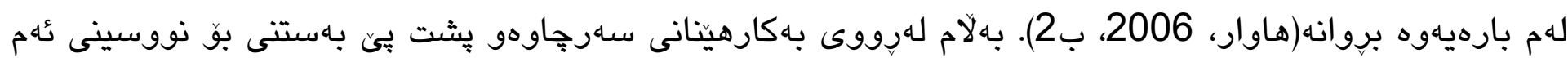

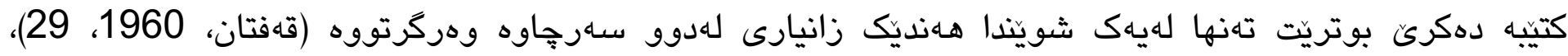

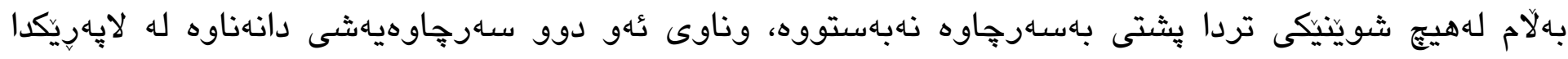

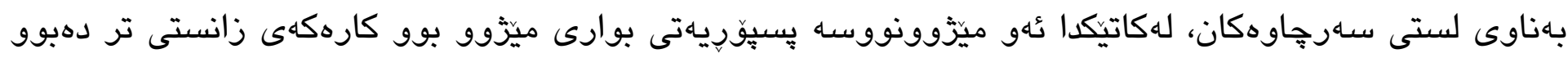

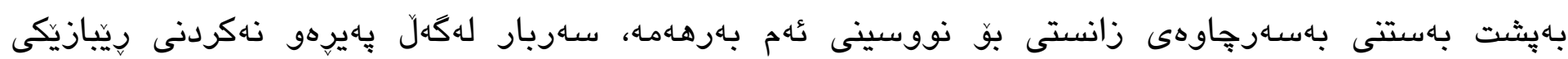

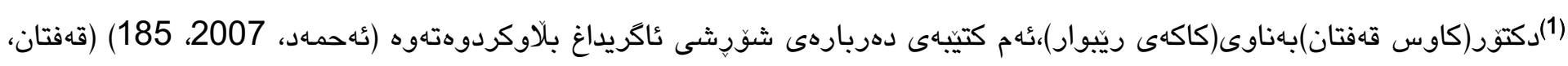

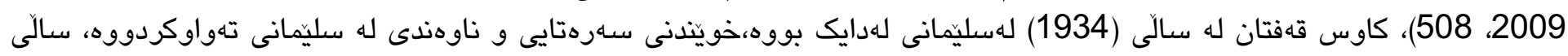

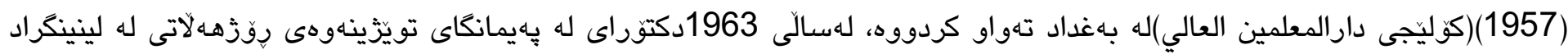

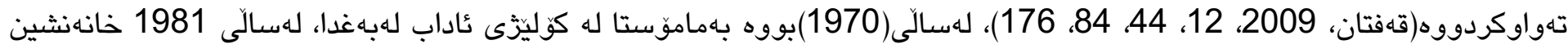

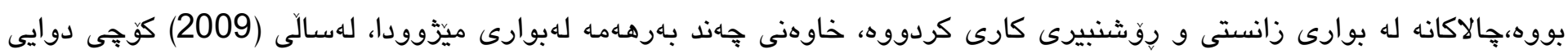
كردووه (البيضانى، 2012، 359-360). 


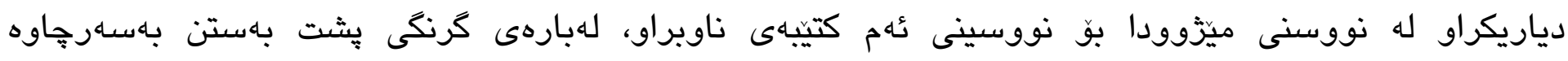

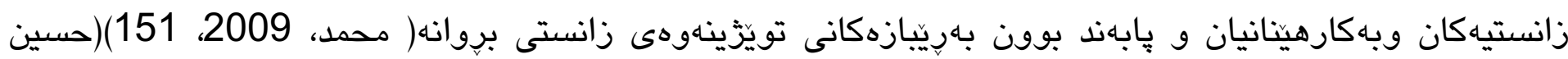

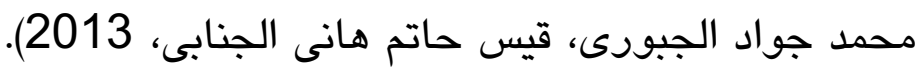

\section{هوارمه/ عوسسان عوزيّرى(1):}

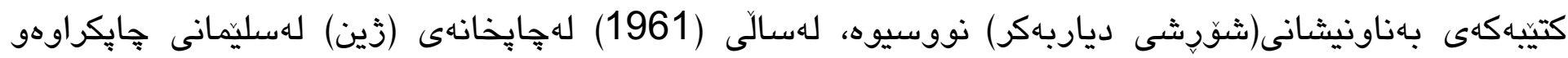

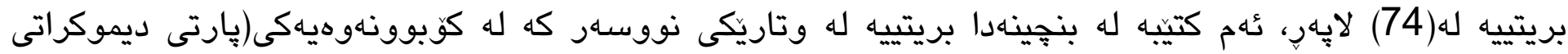

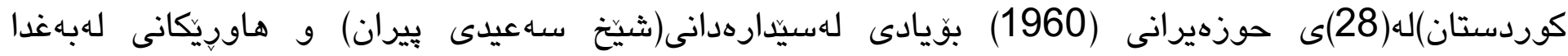

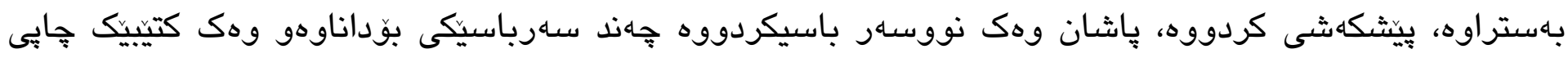

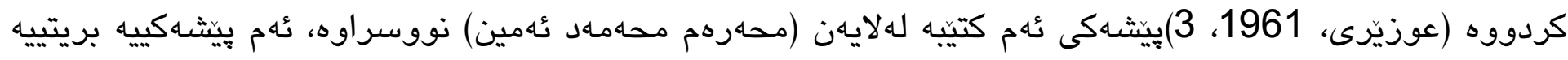

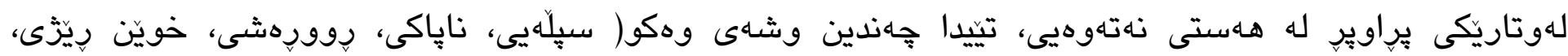

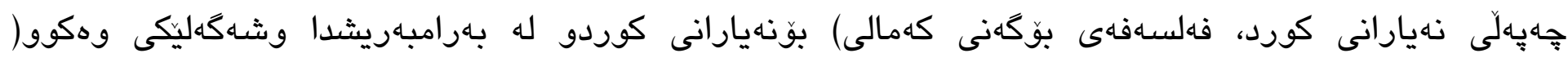

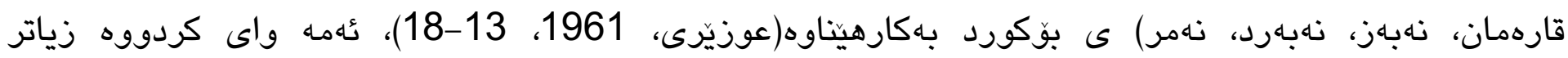

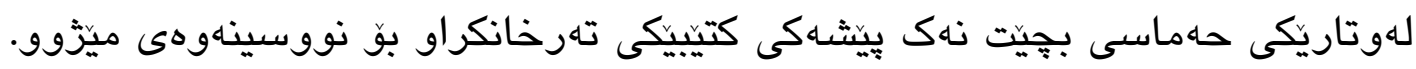

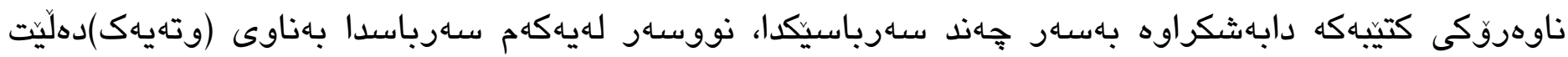

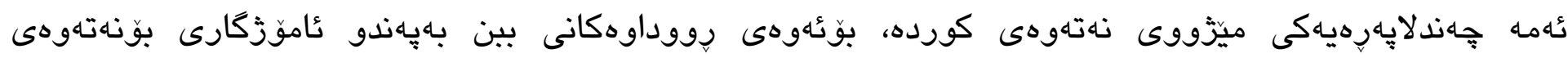

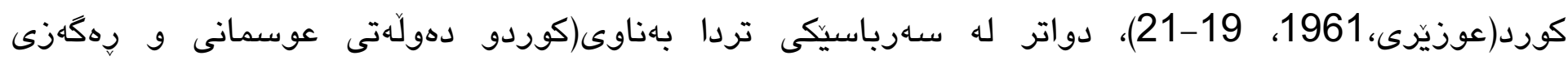

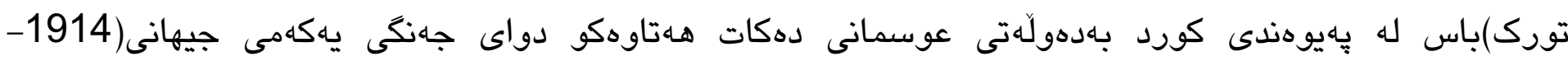

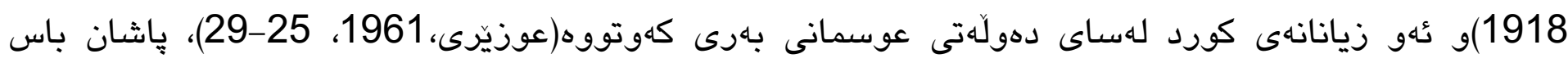

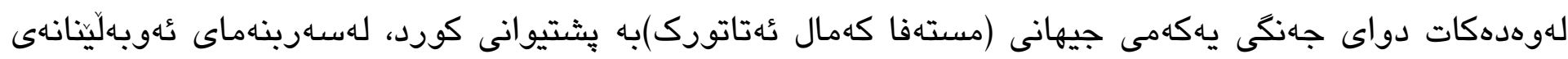

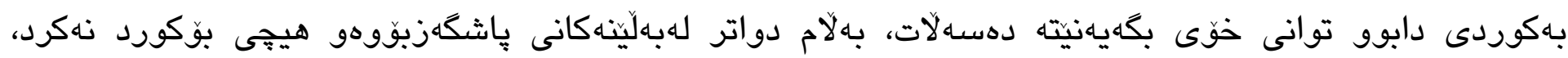

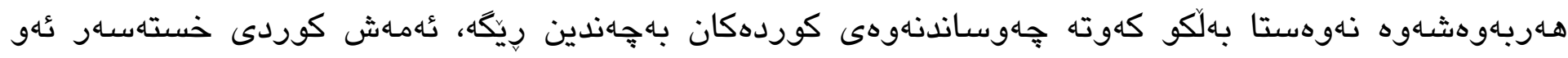

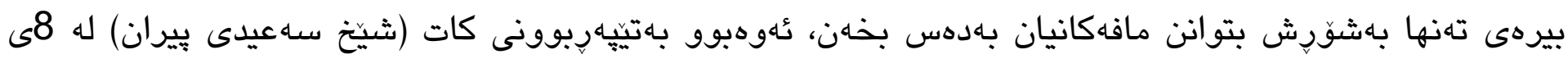

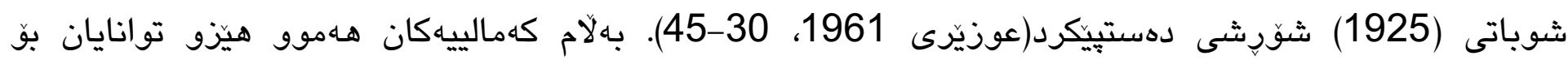

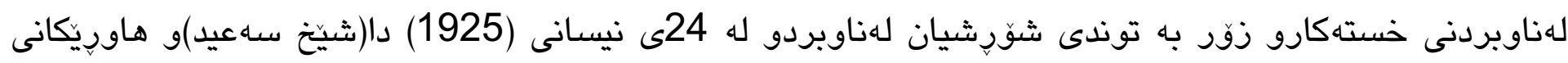

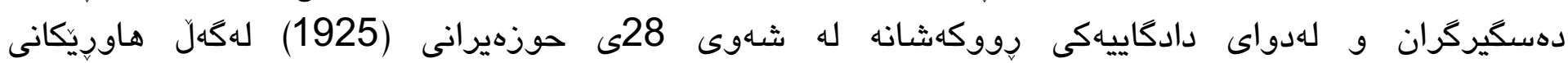

(1) ناوى عوسمان ئهمهاد عوزيّرييه، له سنوورى سليَمانى لهسالى (1933) لهدايك بووه،خوينّنى سارهتايى و ناوهندى له سليمّانى

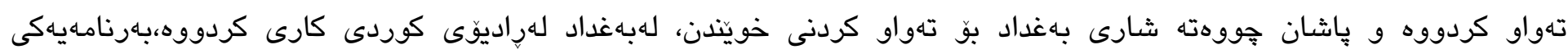

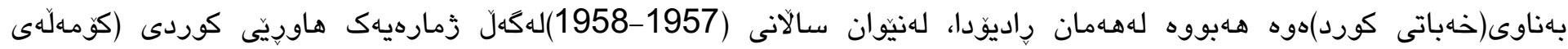

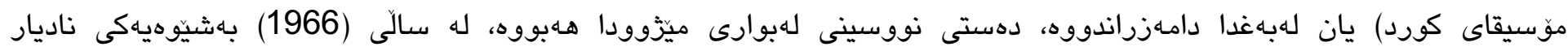

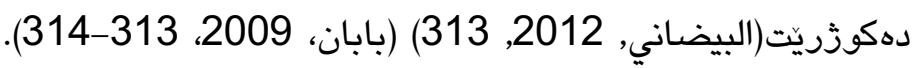




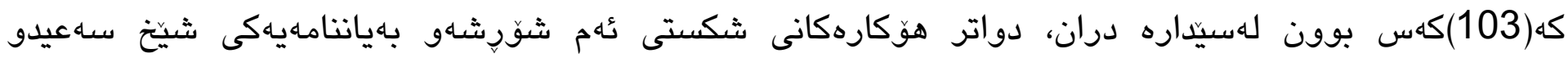

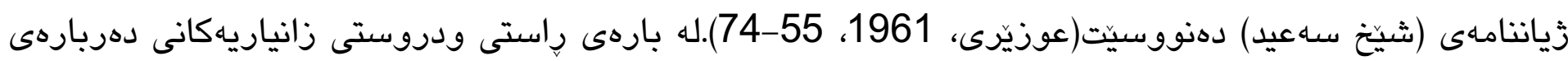

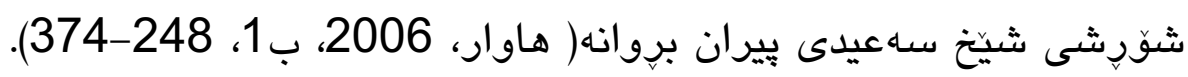

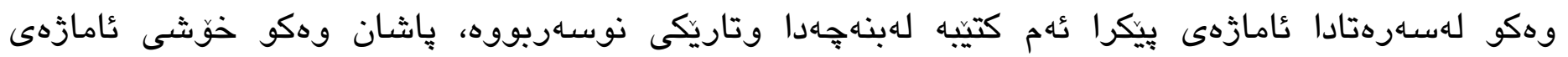

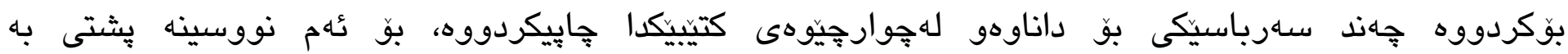

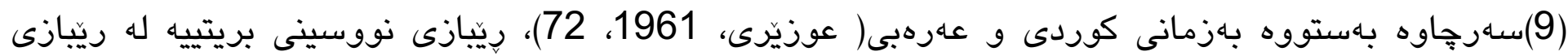

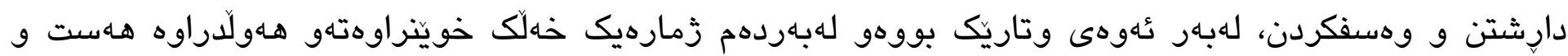

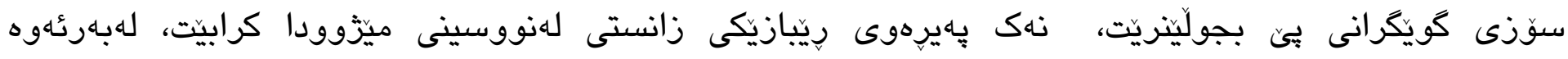

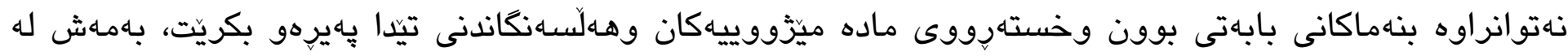

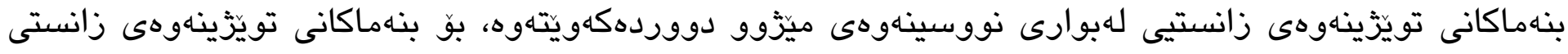

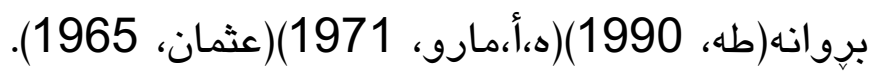




\section{بالثُى دووهم}

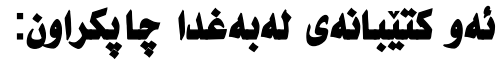

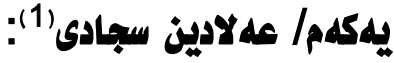

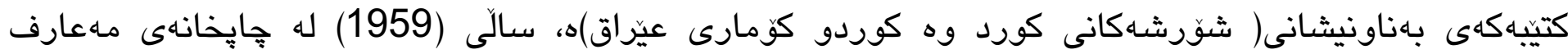

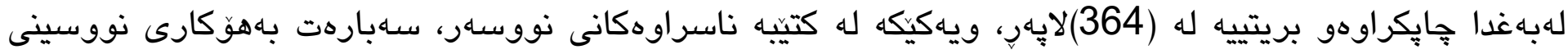

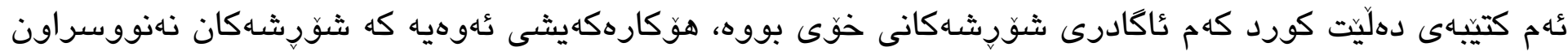

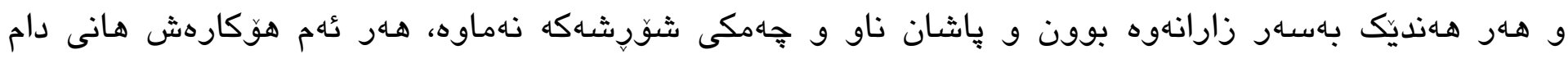

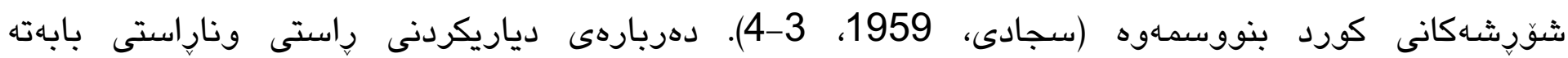

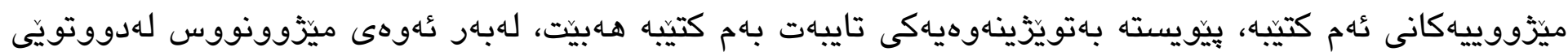

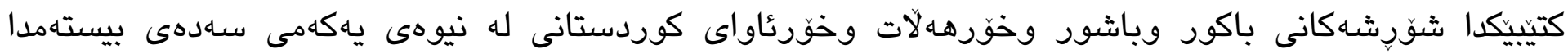
باسكردوه.

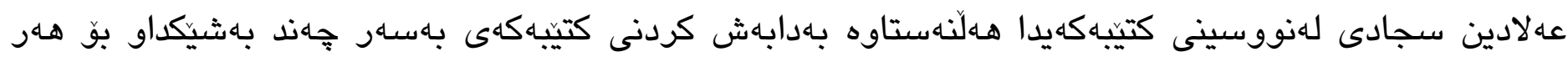

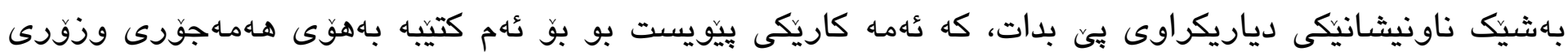

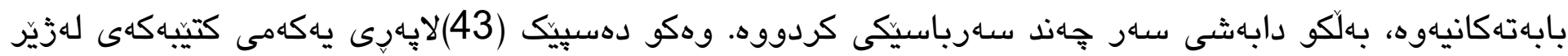

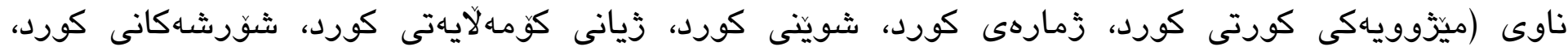

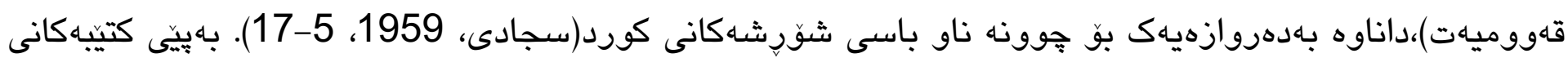

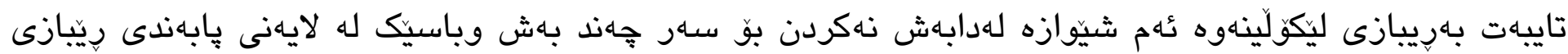

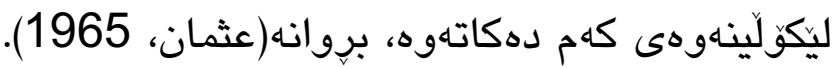

دواتر لهسهرباسيككا بهناونيشانى(شوّرشهانى كورد و قهوميهت )، ئامازه بهوه دهكات كورد شوّرشى زوّرى

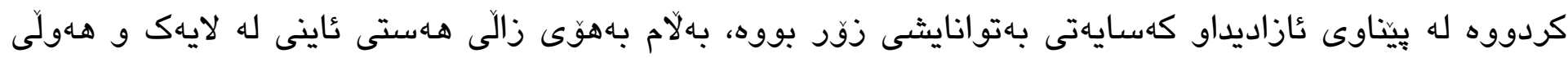

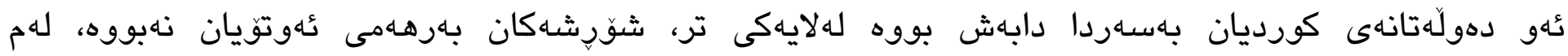

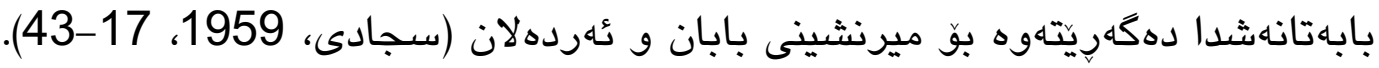

(1) ناوى(عهلادين كورى نهجمهدين كورى عهسامهادين)ه، لهبنهمالهى ناودارى (سجادى) يه له كوردستان (سجادى، 1987، (19) 5) له

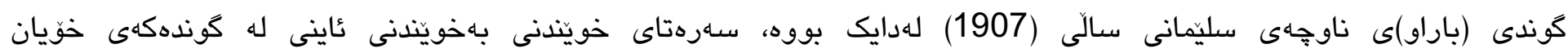

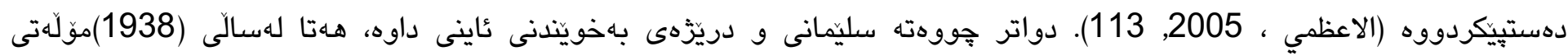

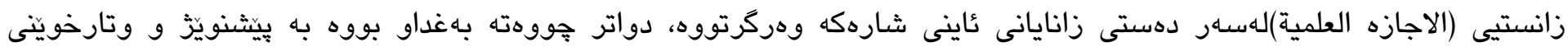

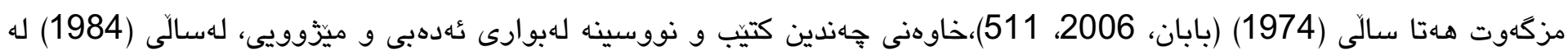

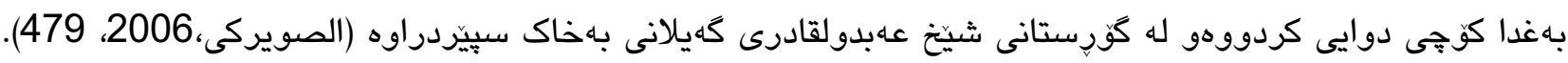




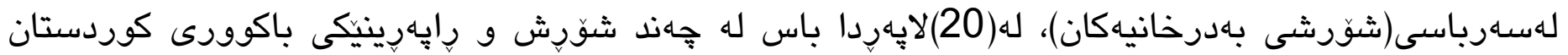

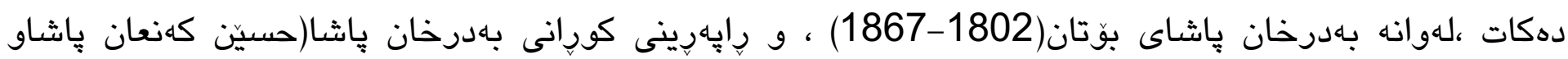

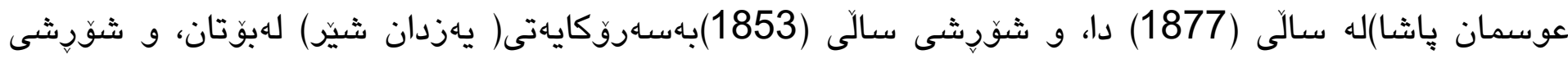

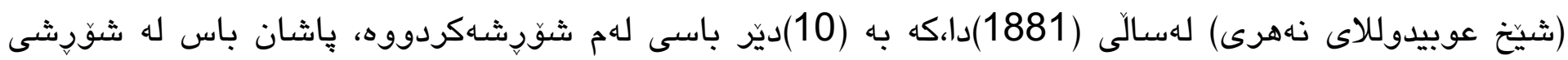

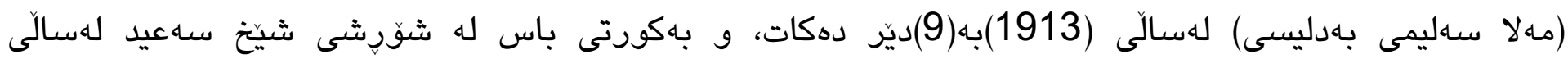

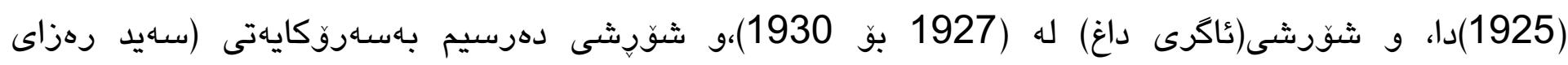

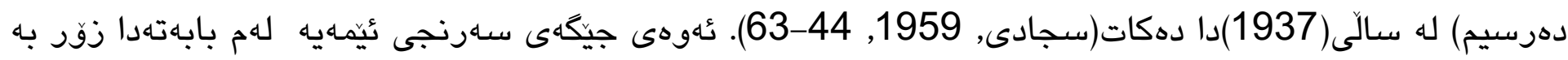

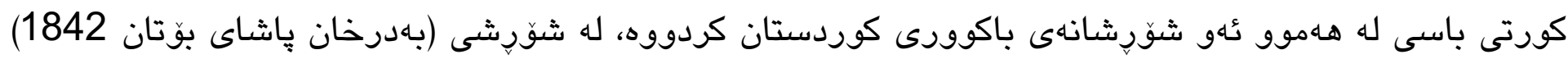

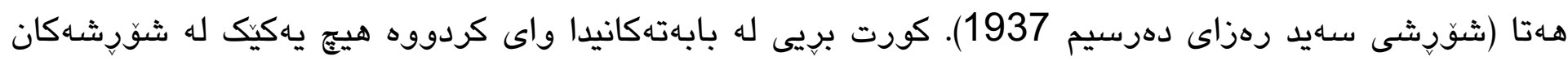

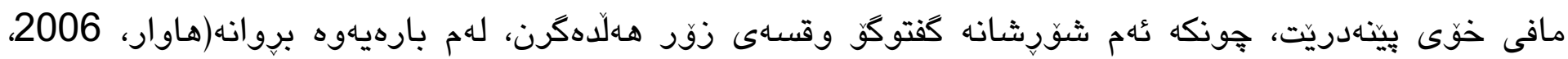

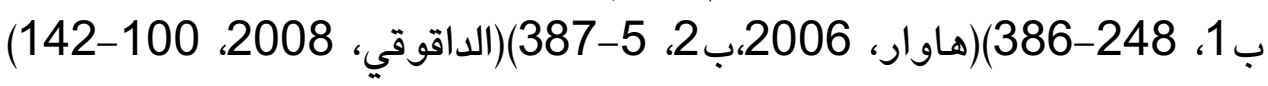

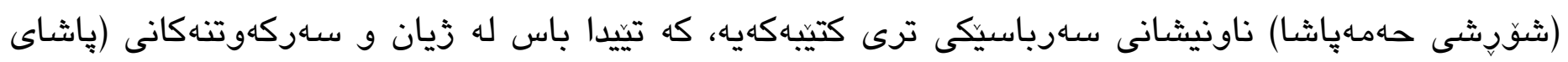

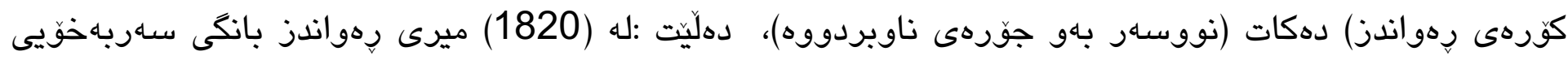

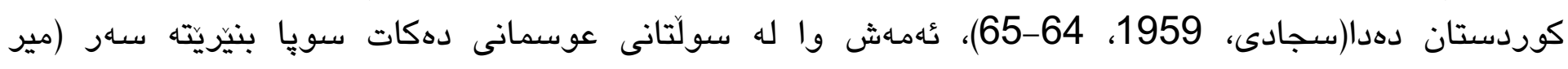

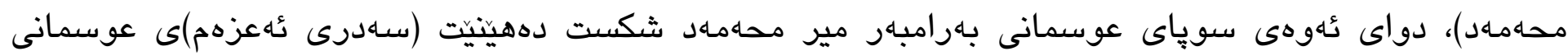

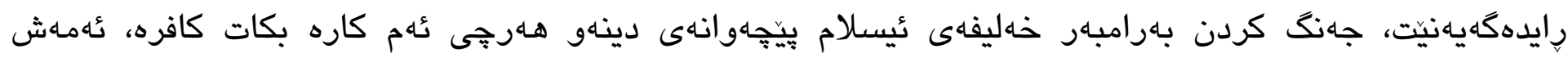

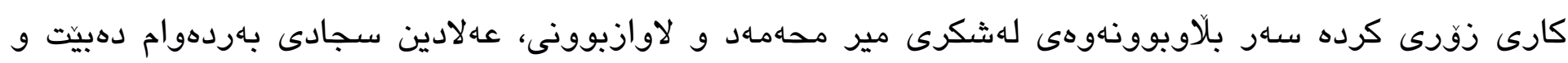

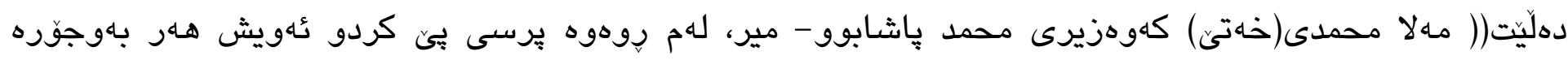

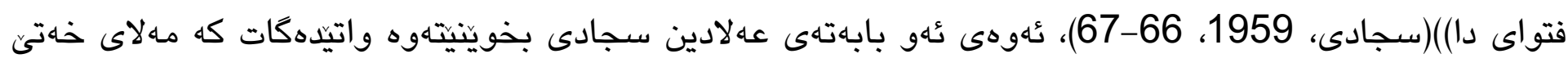

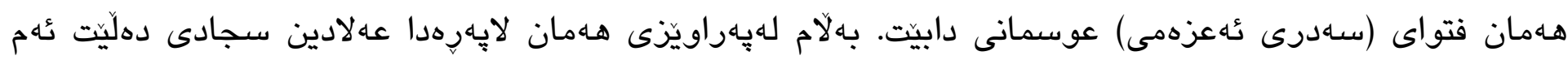

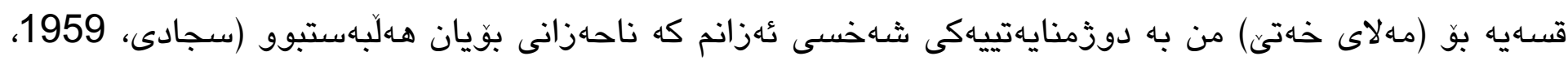

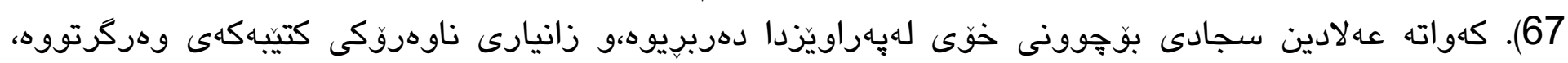

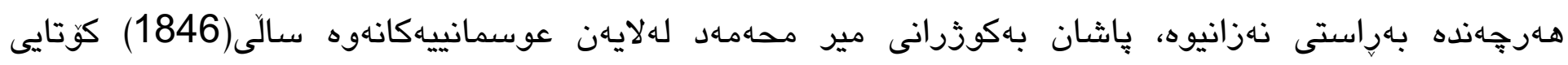

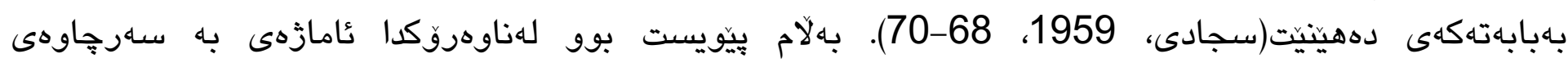

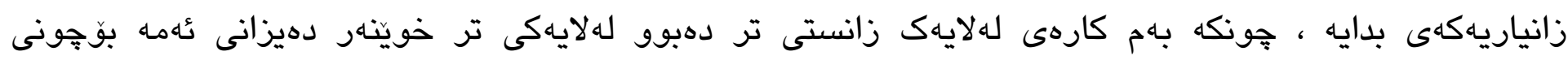

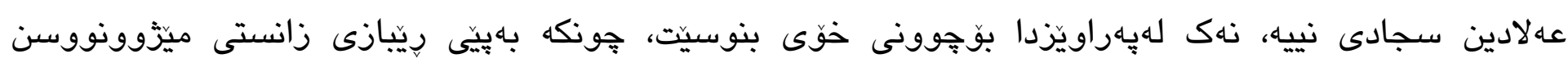

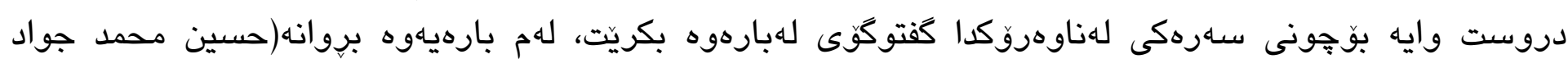

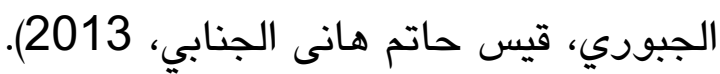

ياشان باس له شوّرشى سهردار رهشيد دهكات كه له ماوهى جهنكى يهكهمى جيهانى(1914-1918)و ماوهى

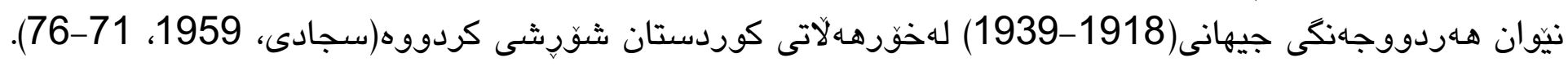

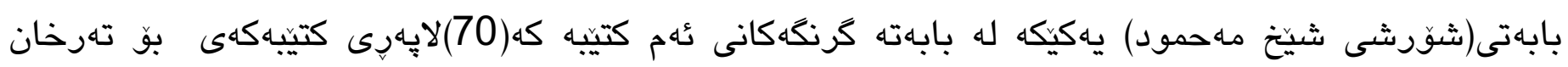

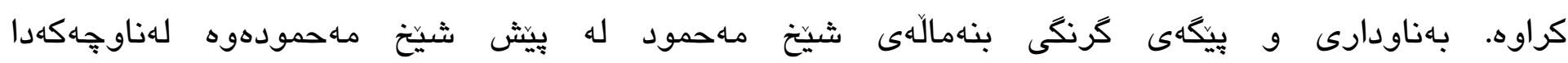




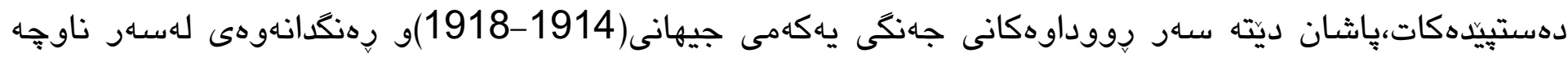

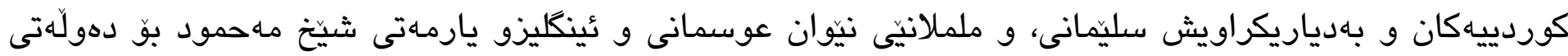

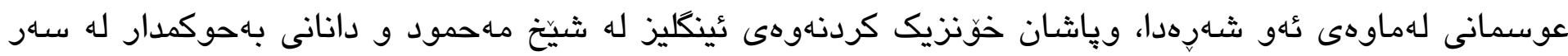

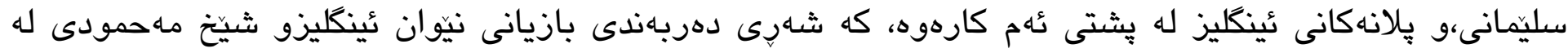

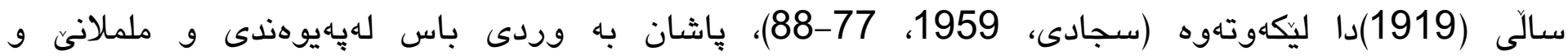

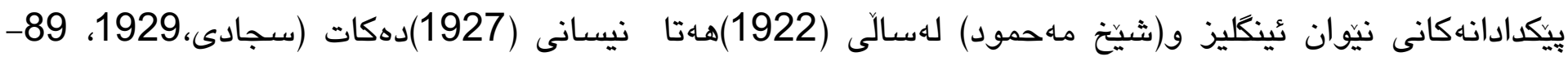

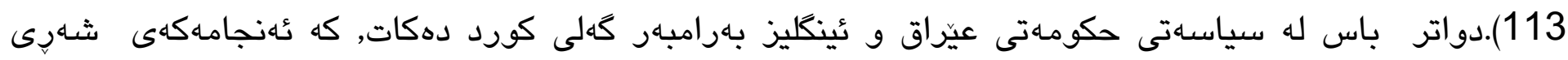

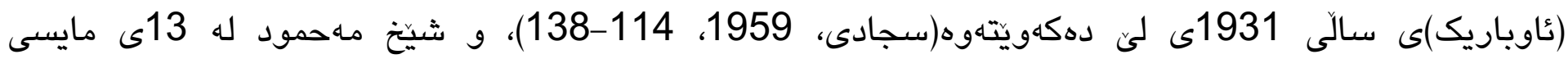

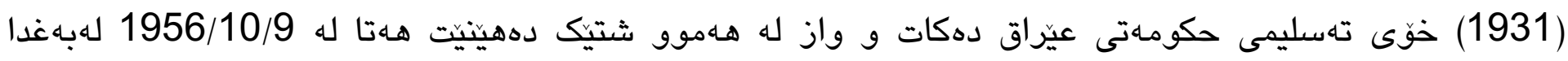

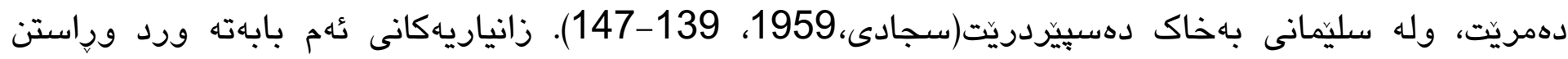

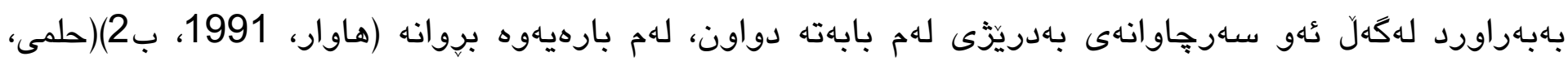

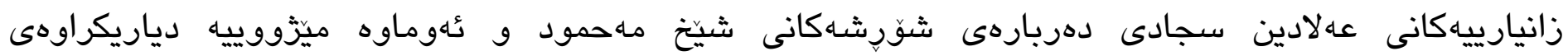

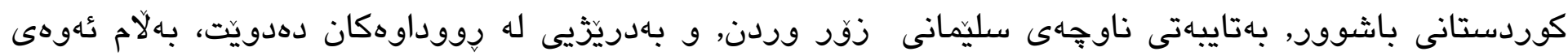

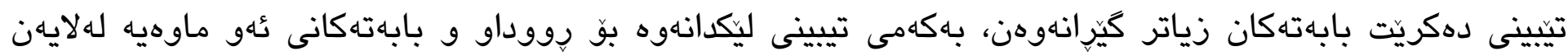

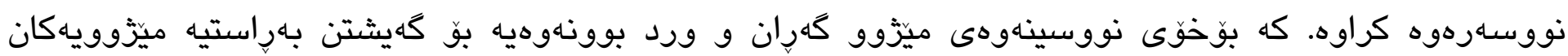

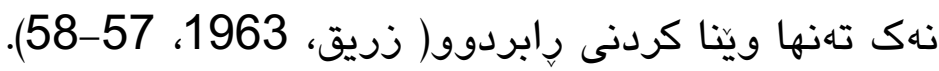

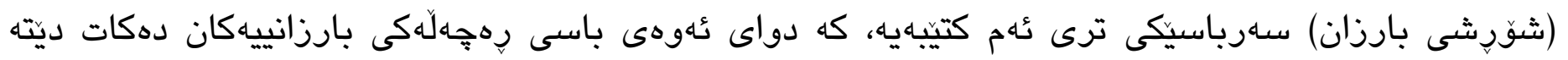

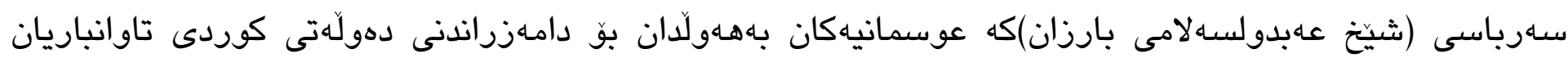

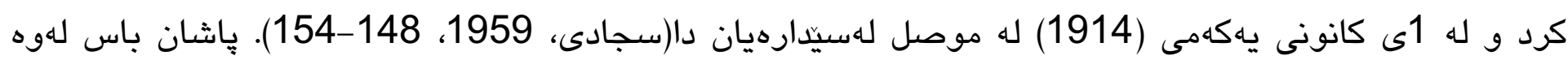

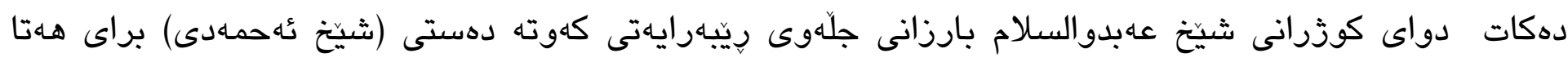

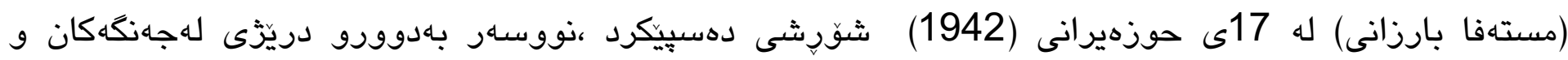

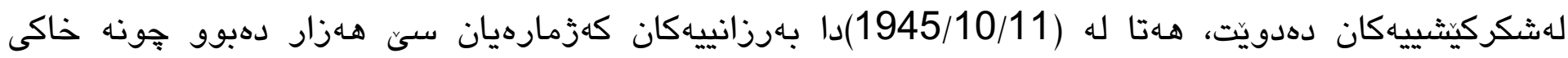

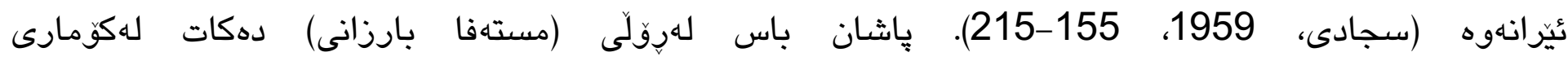

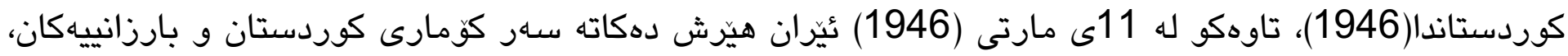

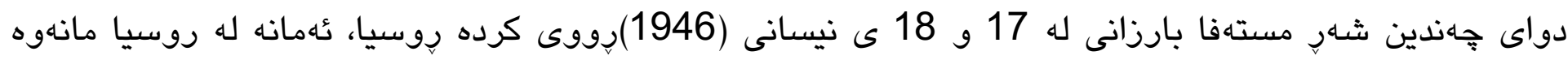

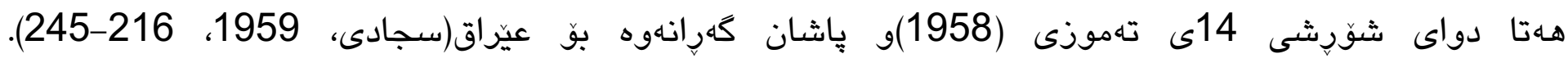

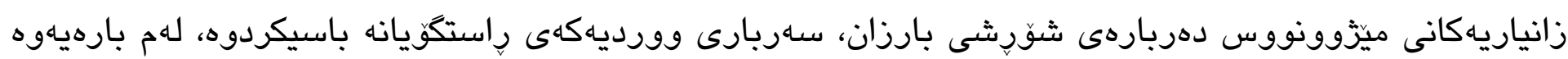
بروانه(البارزانى، رئى 1986)(البارزانى، 1987).

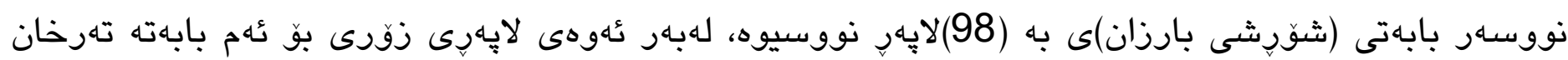

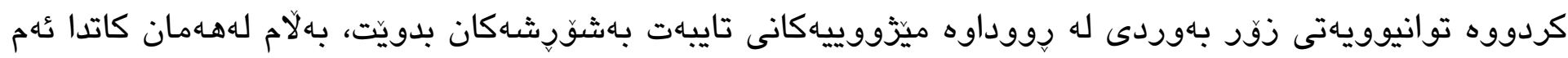

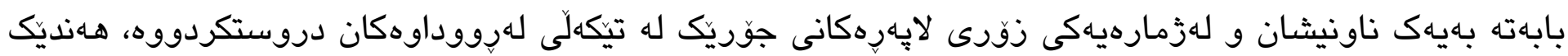




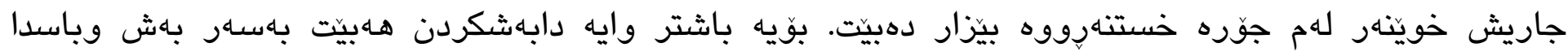

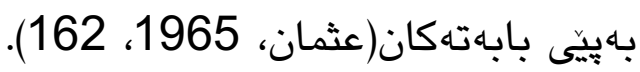

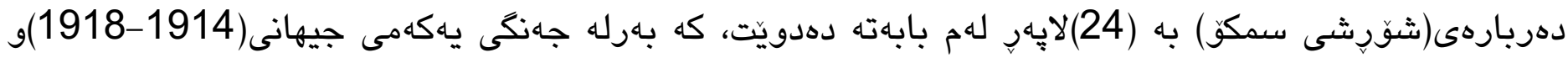

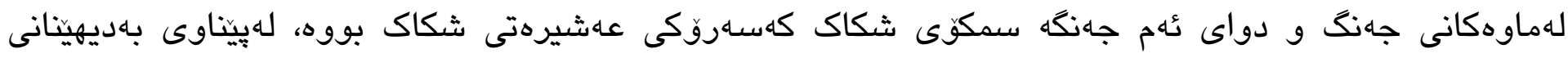

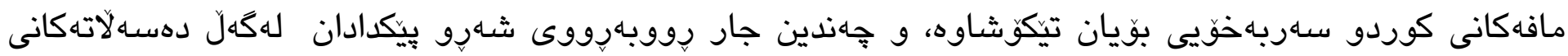

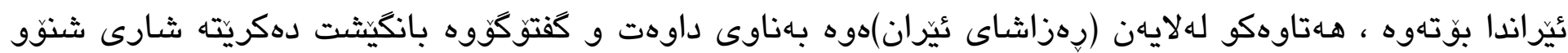

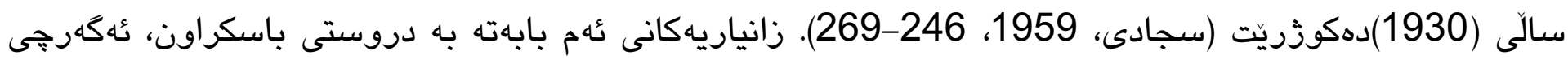

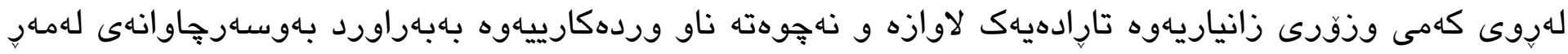

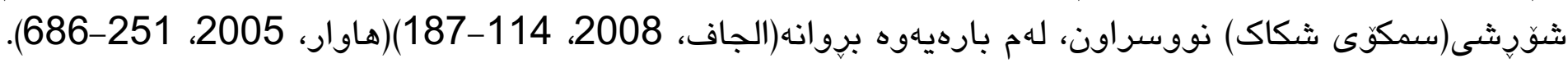

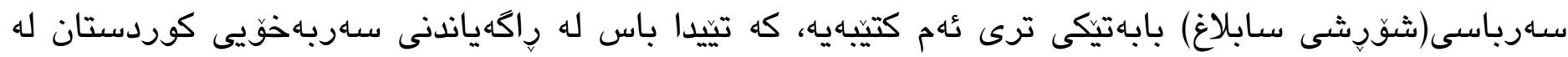

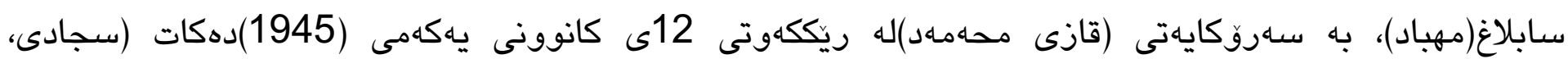

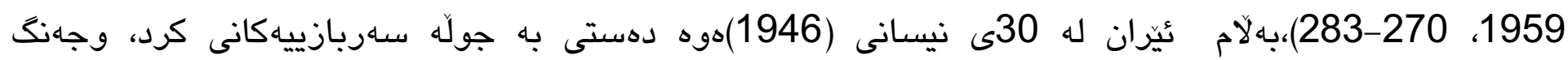

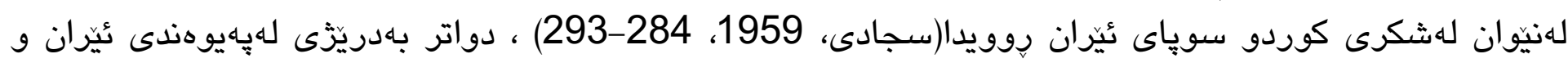

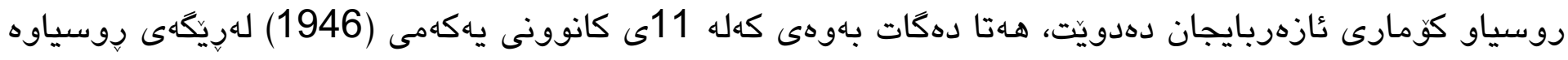

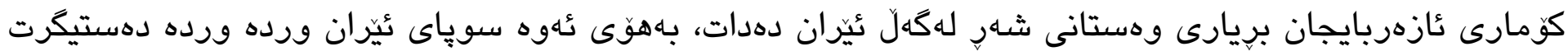

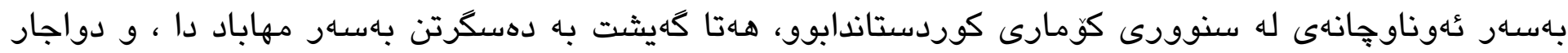

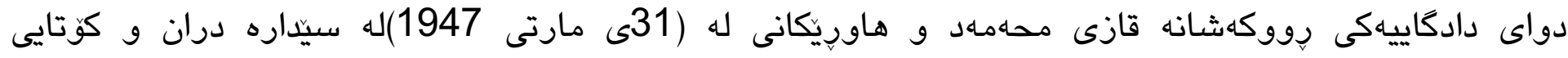

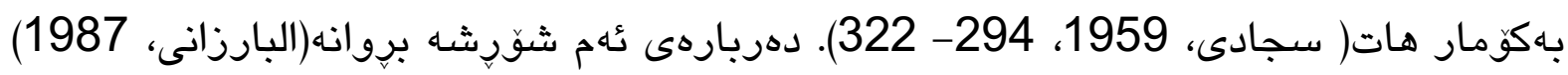

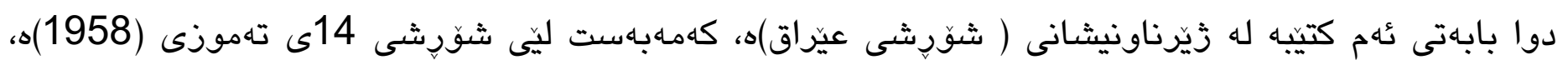

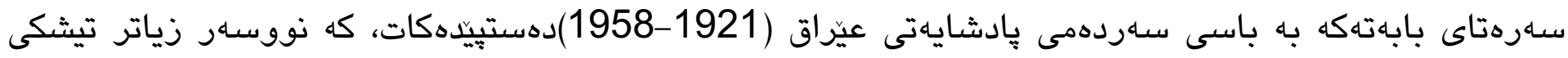

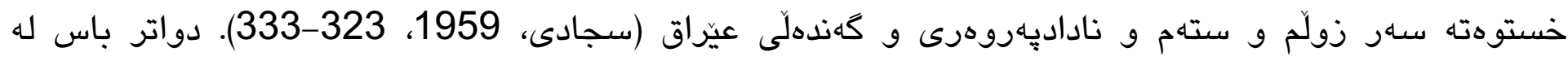

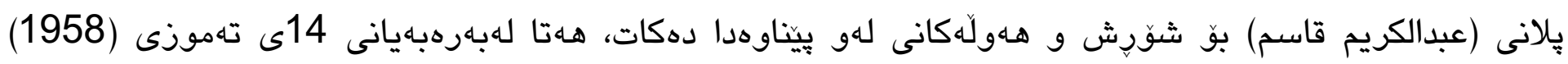

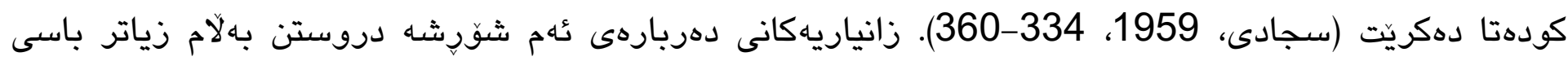

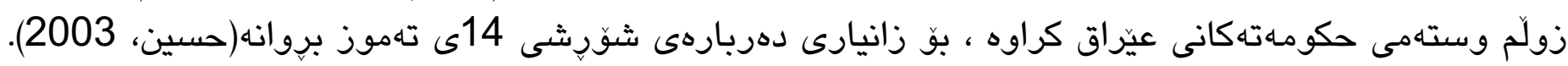

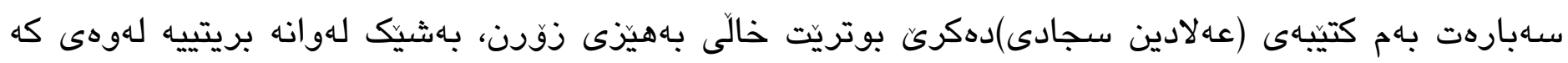

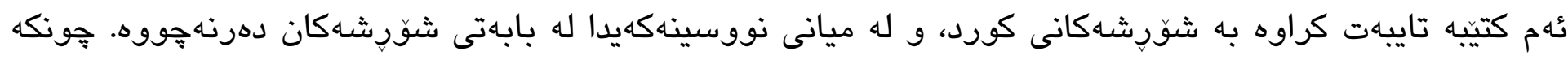

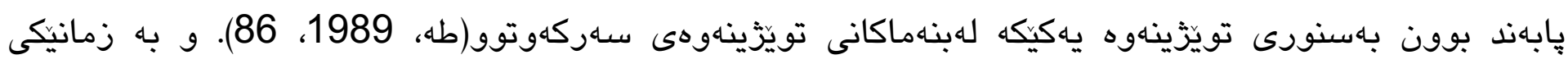

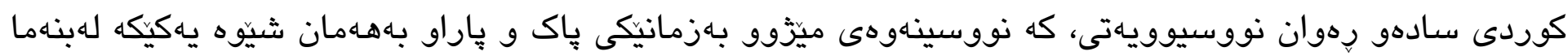

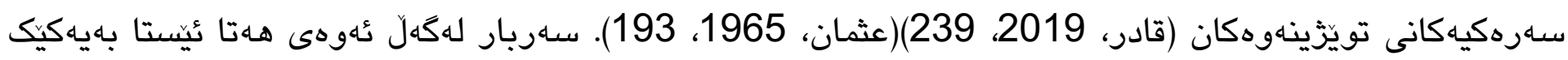

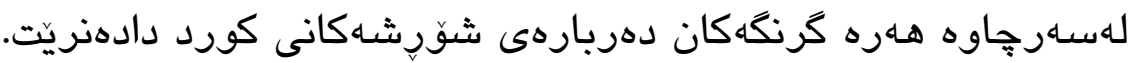




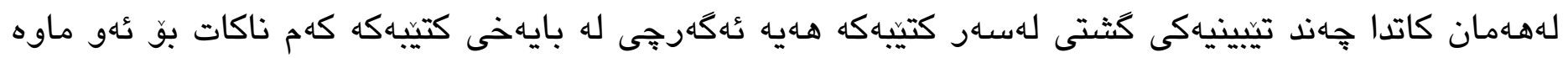

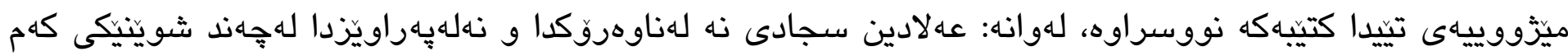

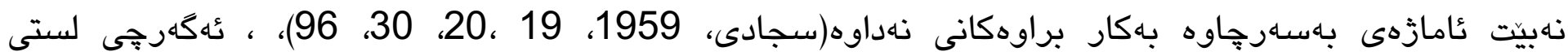

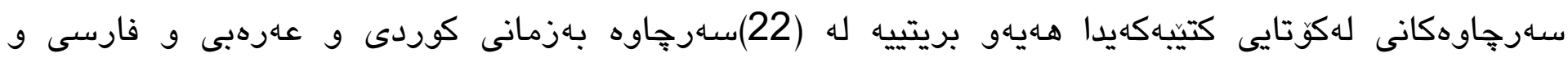

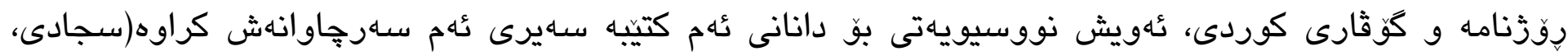

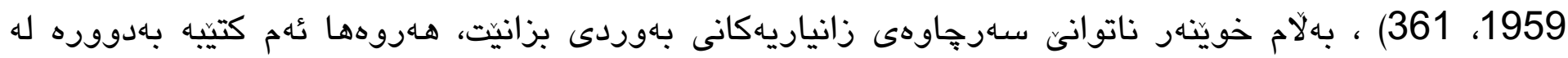

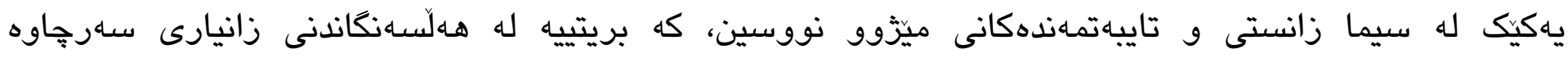

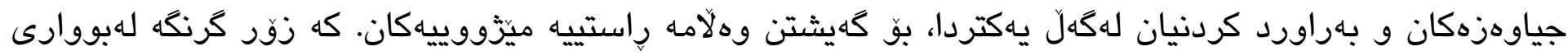

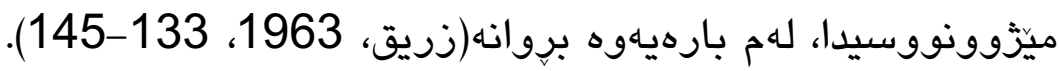

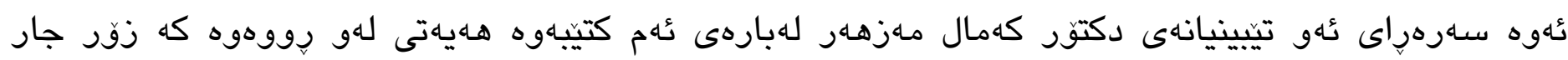

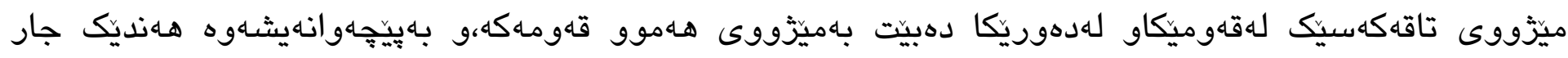

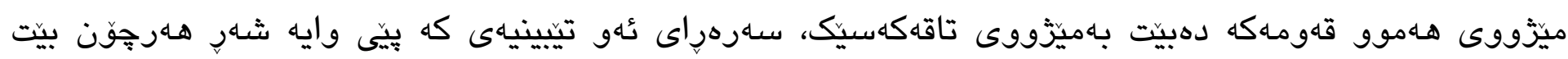

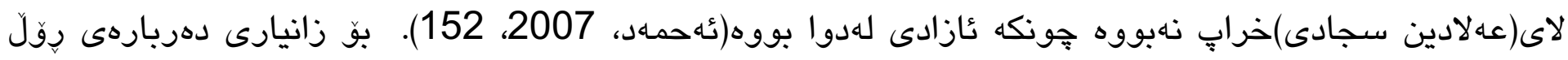

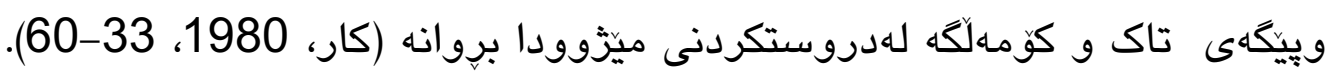

\section{دووهم/ محdمهد توضيق ووردى(1):}

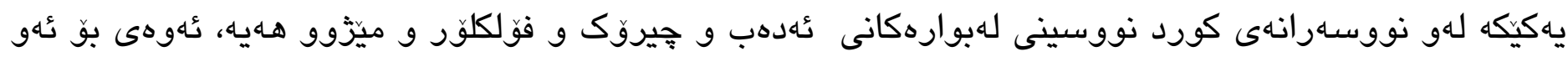

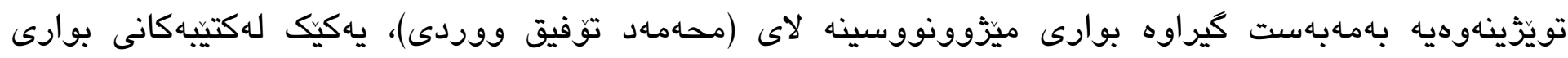

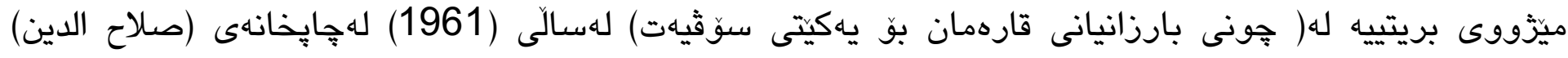

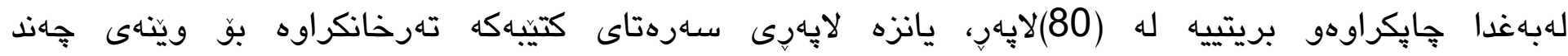

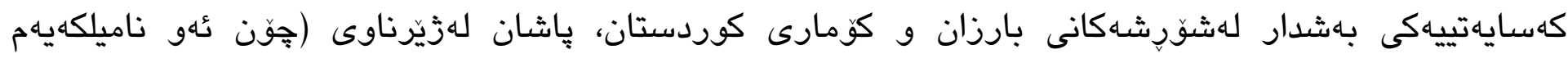

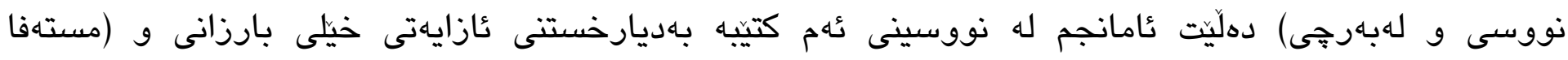

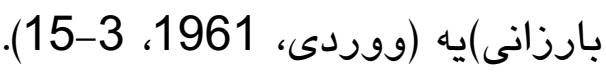

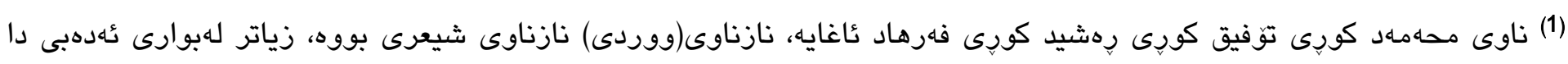

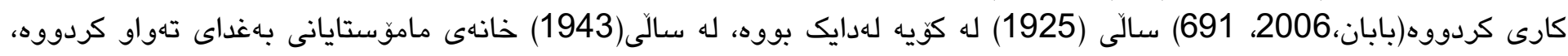

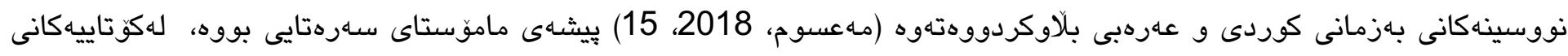

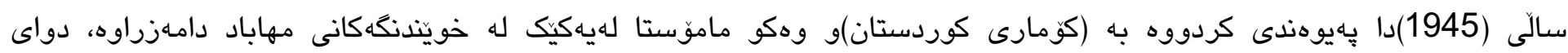

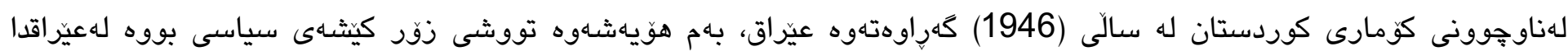

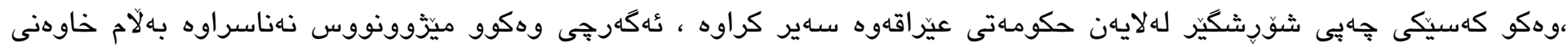

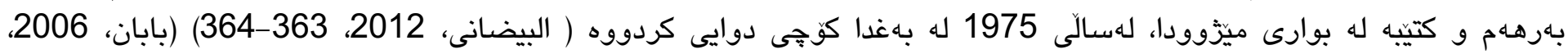

.693-691 


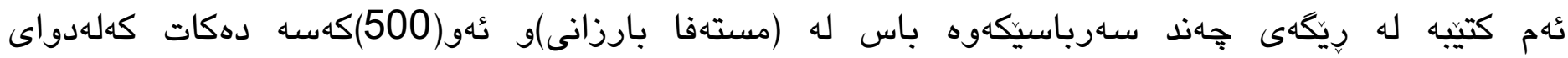

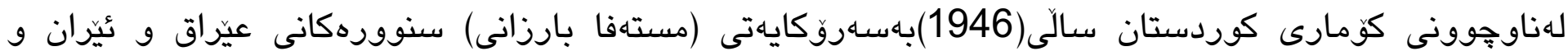

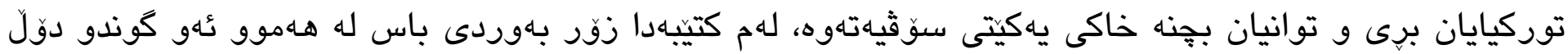

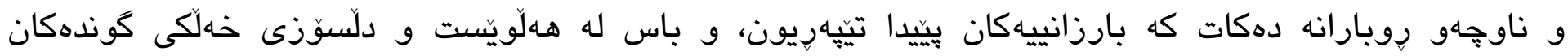

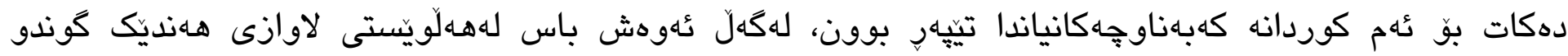

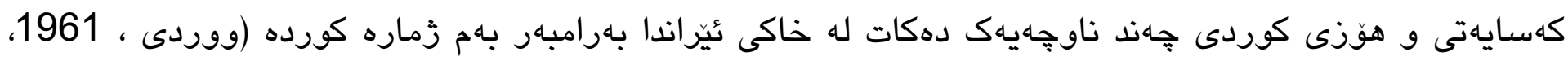

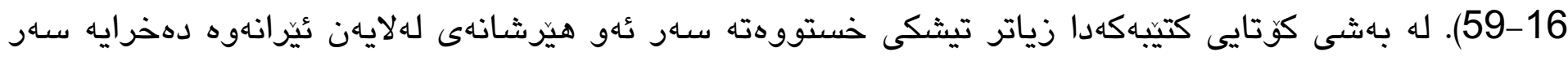

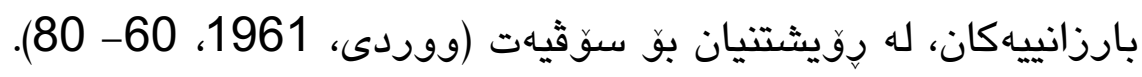

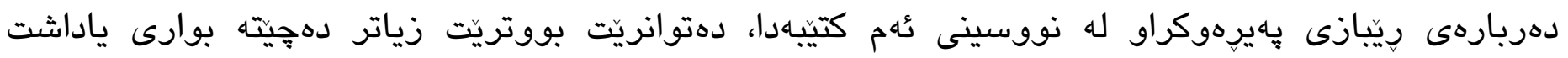

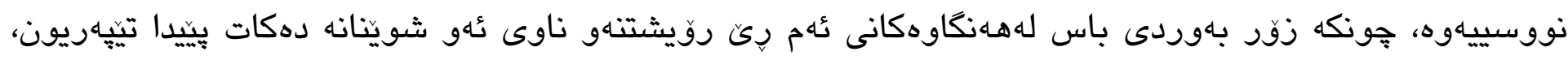

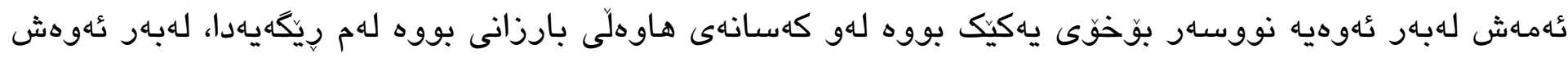

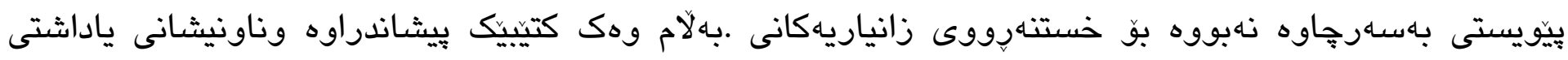
وهرنه

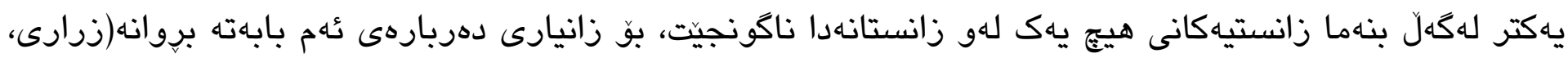

.(2019

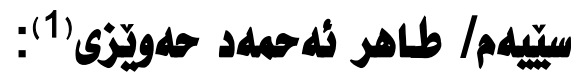

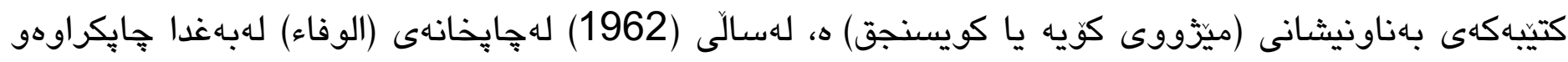

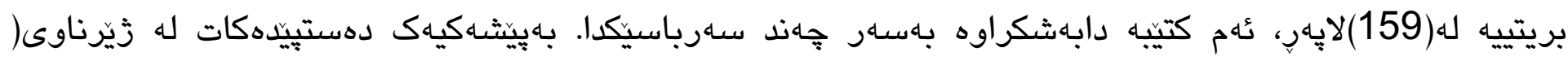

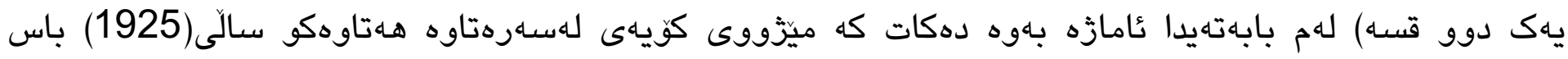

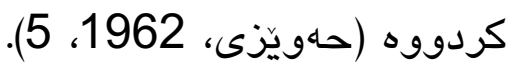

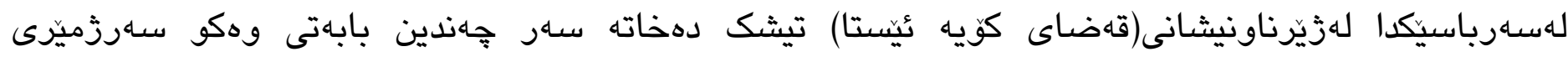

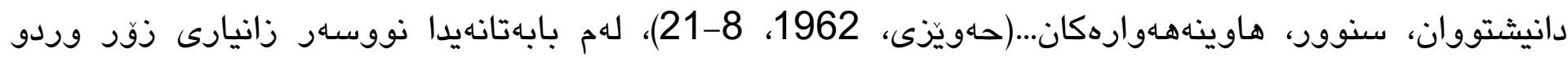

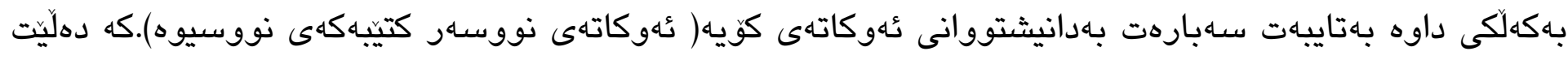

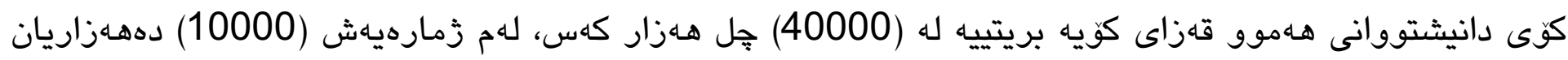

(1) ناوى طاهر كورى ئهمده كورى سادق كورى بهكرئاغاى حهويزييه، لهسالى (1919) لهقهزاى كويه لهدايك بووه، خوينتدنى

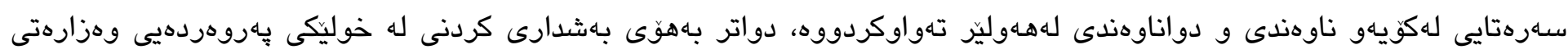

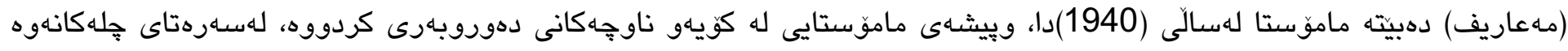

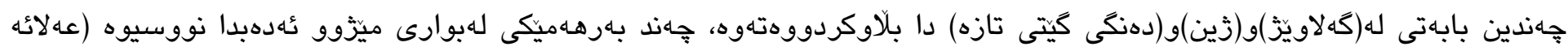
دين، 2014، 317-318). 


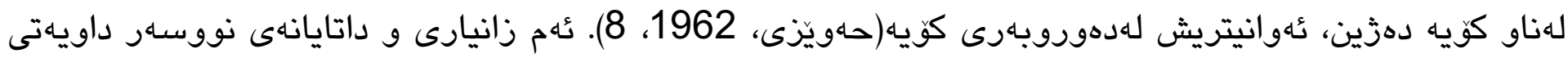

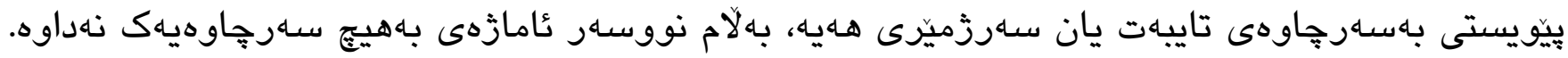

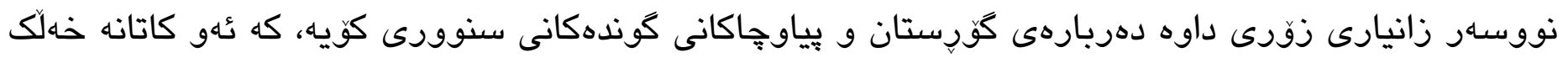

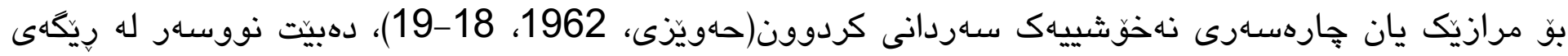

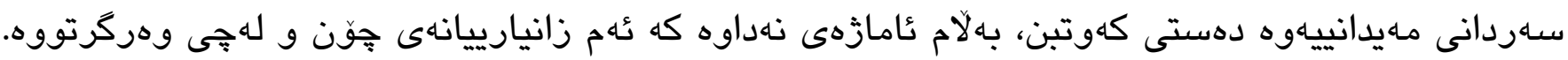

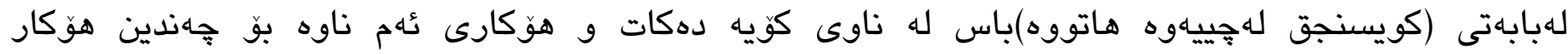

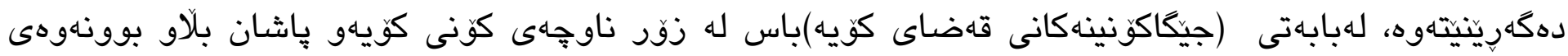

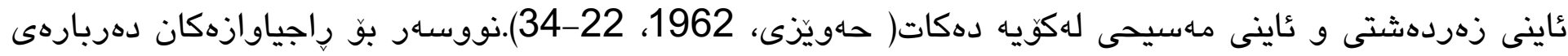

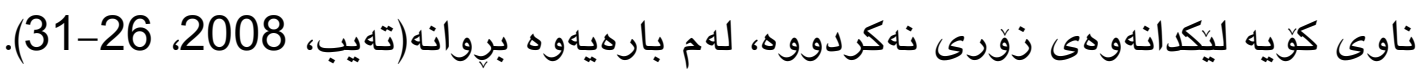

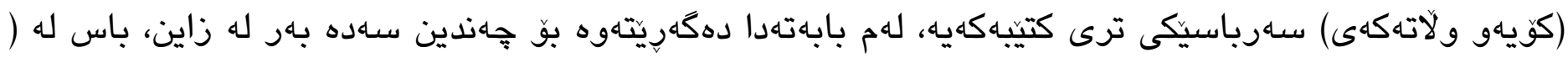

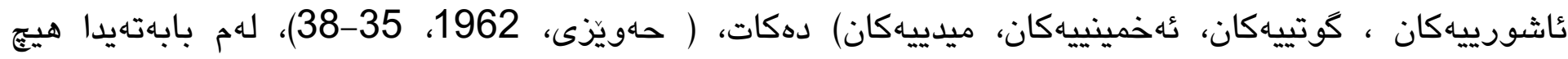

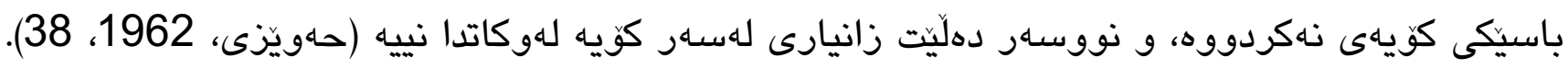

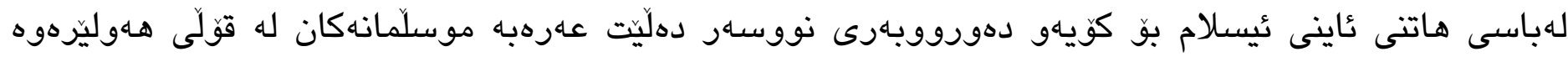

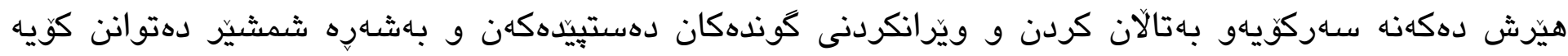

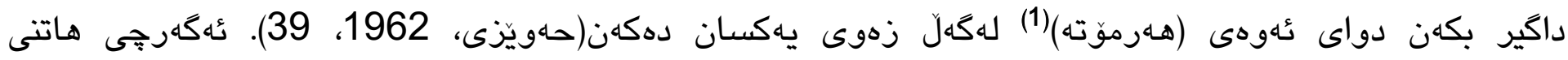

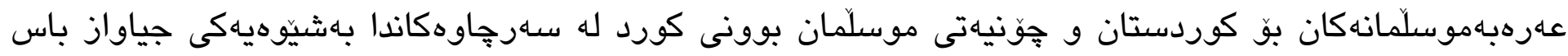

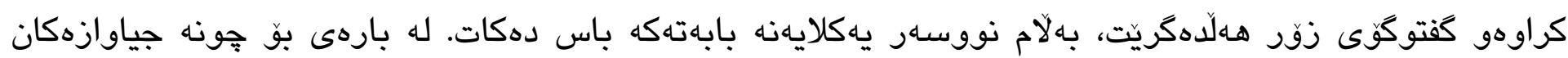

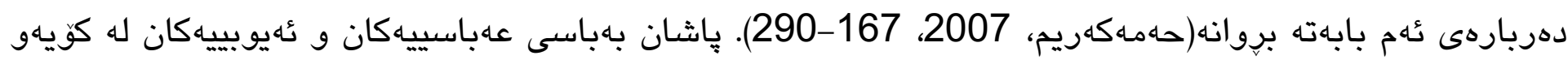

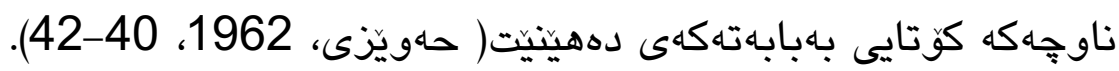

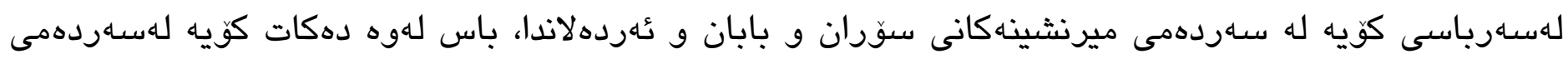

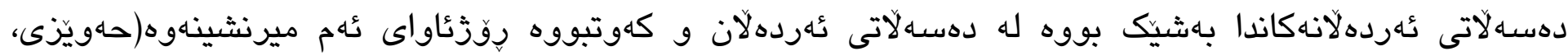

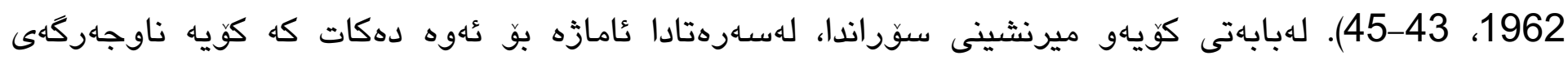

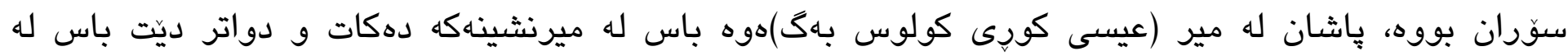

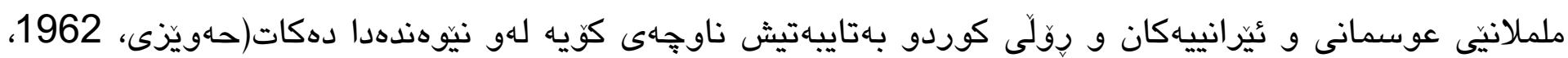

للهباباتى (بابانهكان لهكويه) زياتر باس لهو فهرمانرهواو دهسهلاتدارانه دهكات كه ميرنشينى بابان لهاهـهر

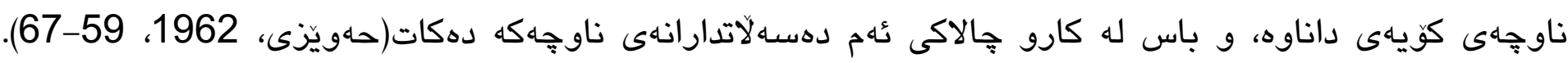

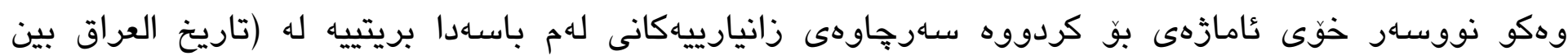

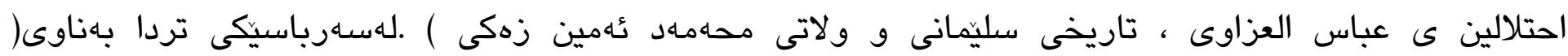

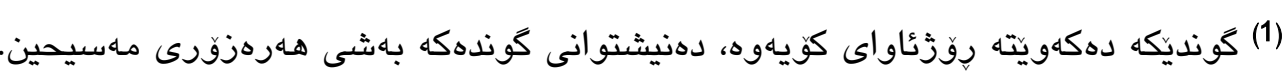




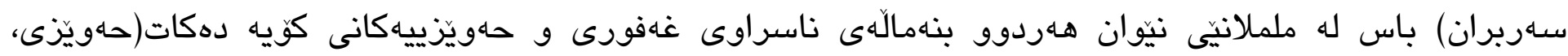

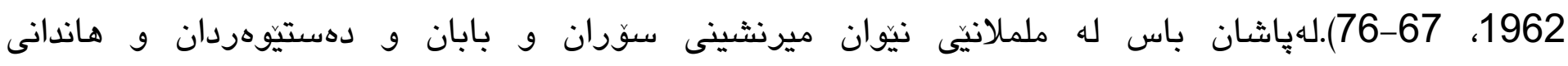

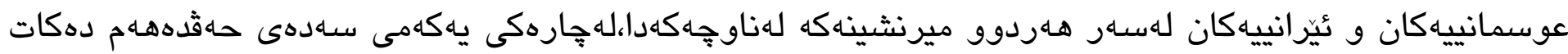

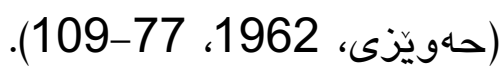

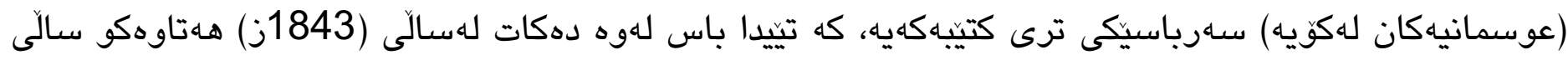

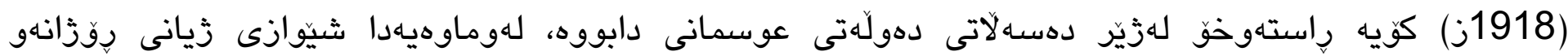

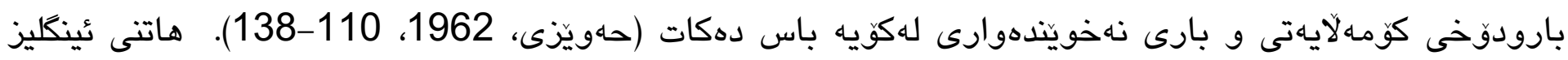

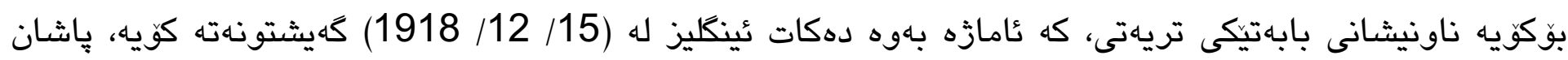

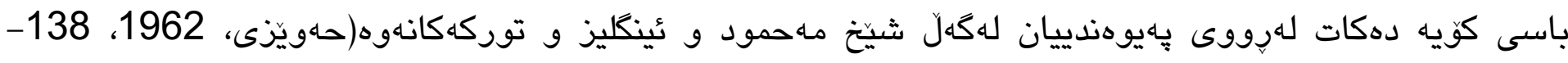

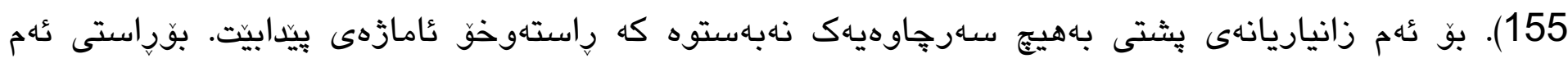

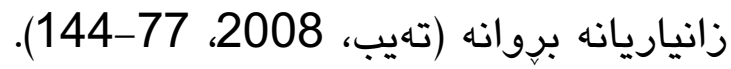

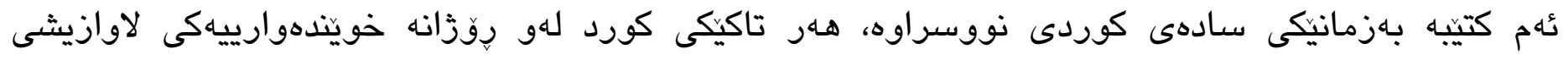

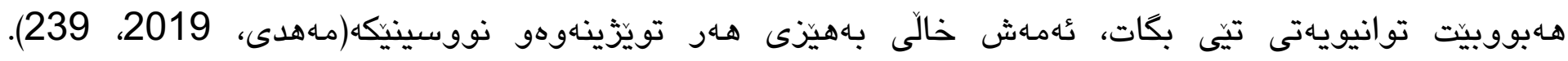

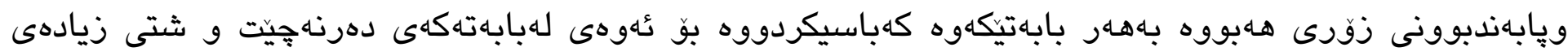

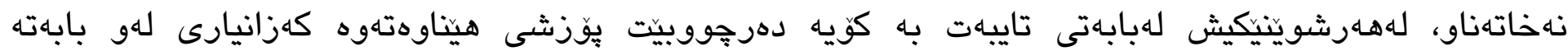

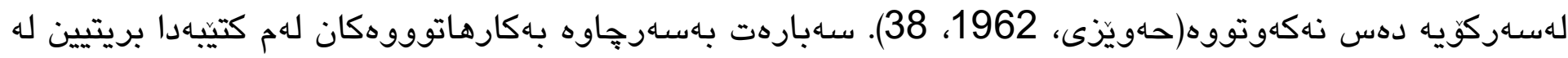

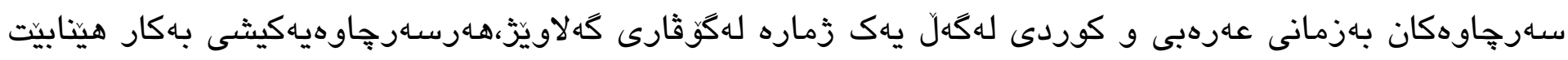

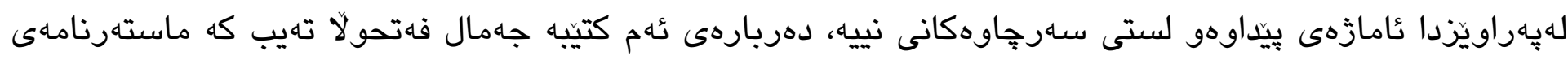

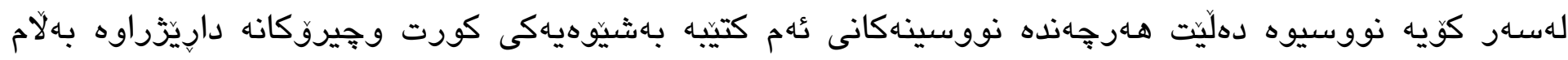

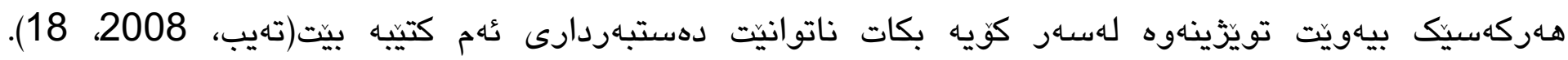

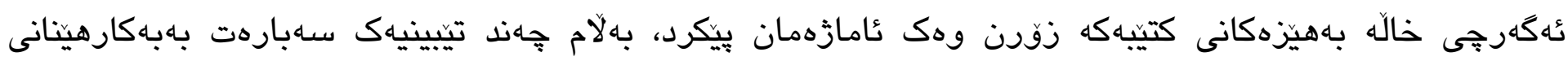

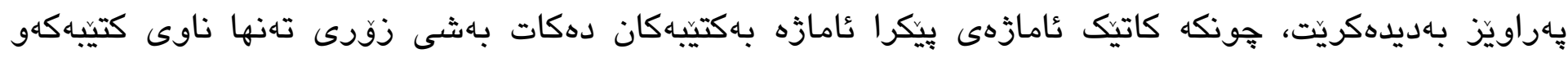

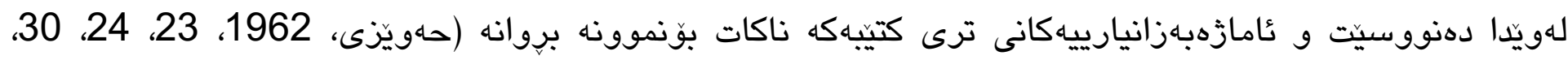

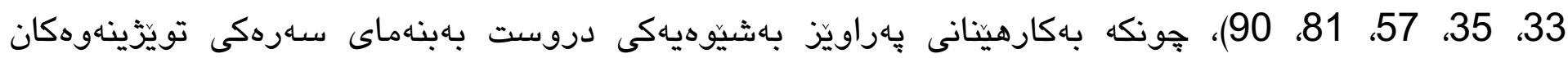

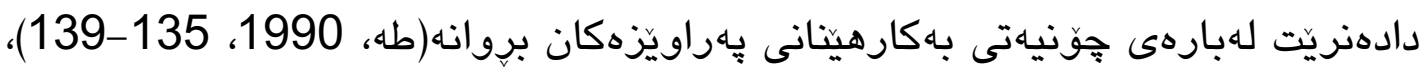




\section{: جواربم/ ثلهمد خواجه}

كتيبه كهى به ناونيشانى (جيم دى) بريتييه له ياداشتهكانى ئهماهد خواجه كهنووسهار لهسئ بهركدا نووسيويهتى،

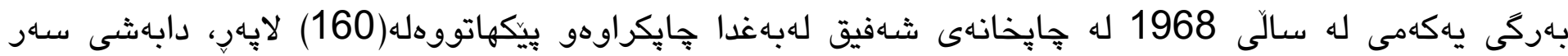

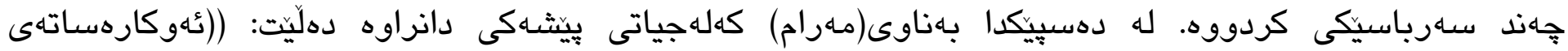

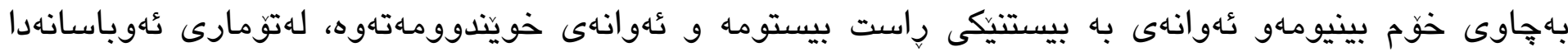

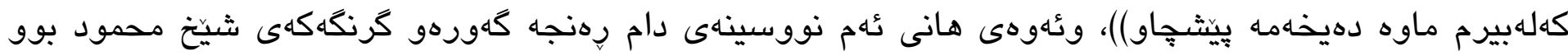

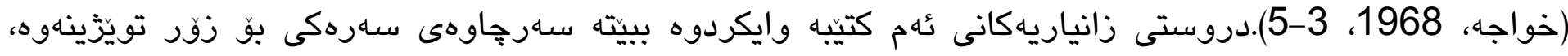

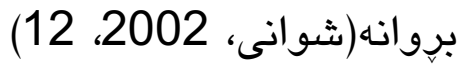

لهسهرباسيكدا بهناوى كورد لهباوى عوسمانى دا باس لهوهدهكات كوردهكان بهاسهوروكايهتى شيخّ مهاهمود

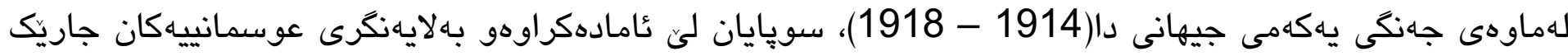

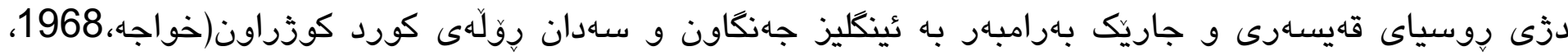

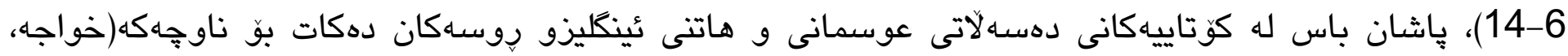

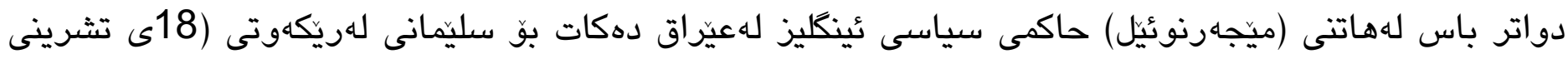

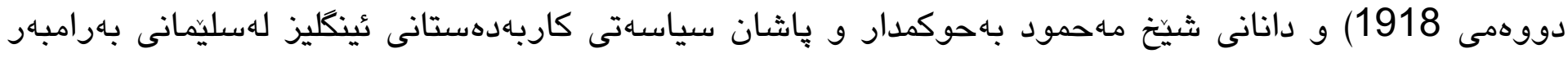

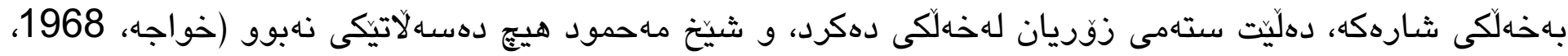

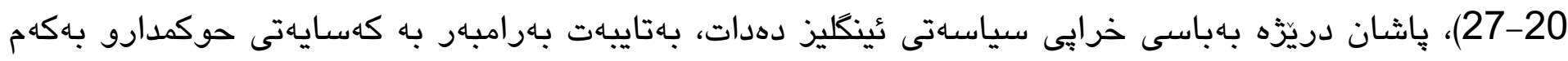

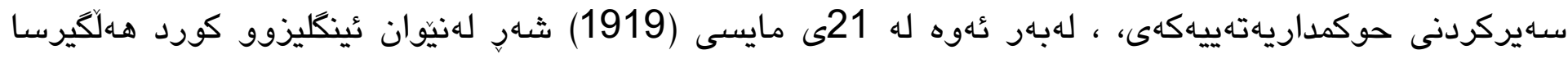
(خواجه، 1968، 27-38)

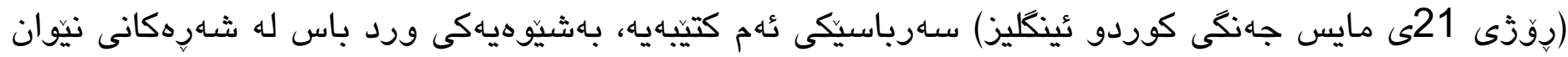

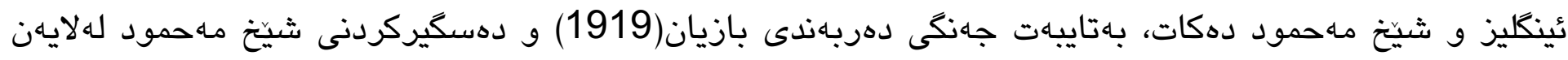

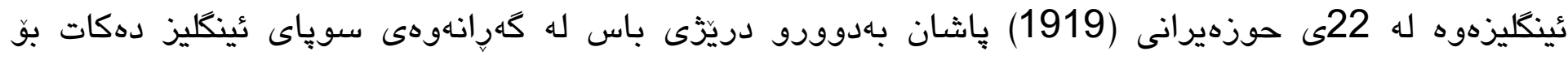

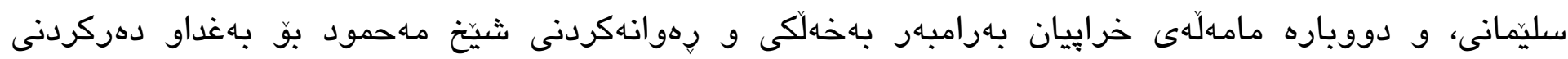

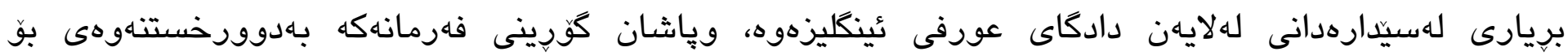

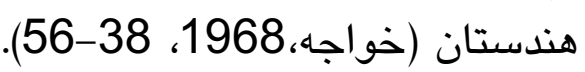

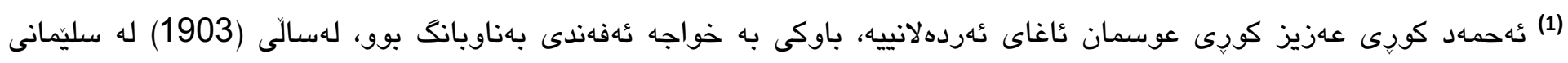

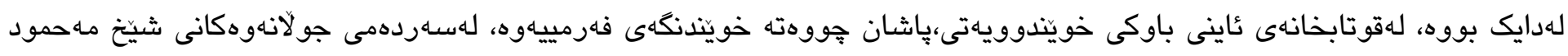

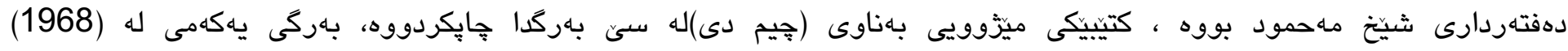

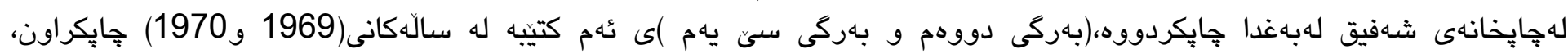

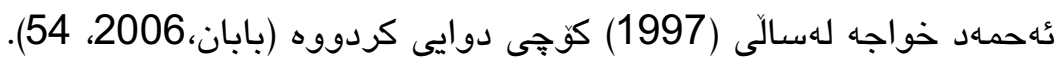




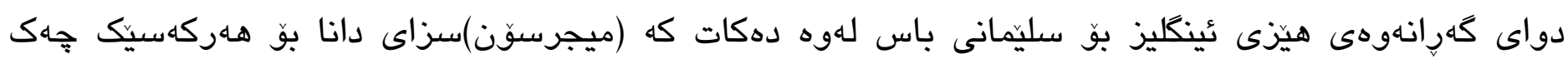

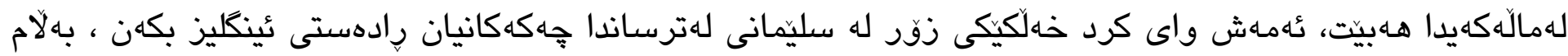

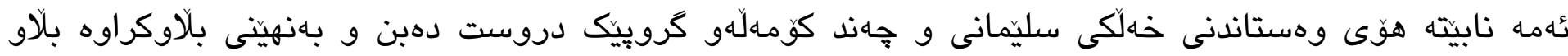

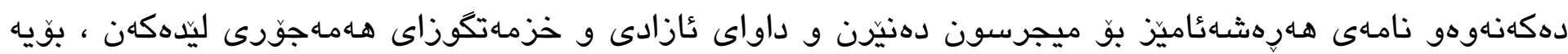

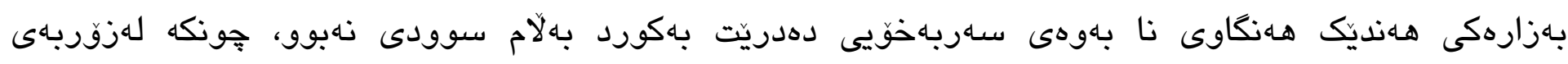

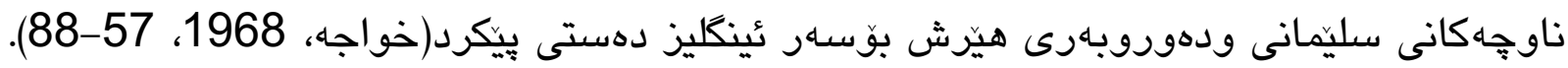

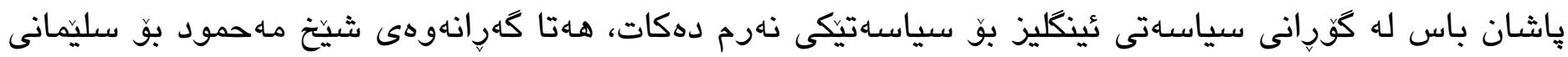

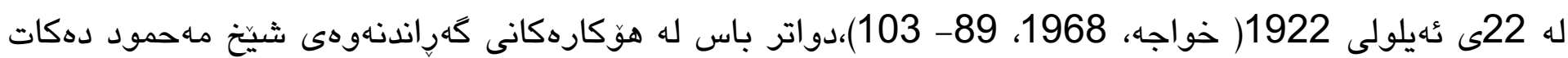

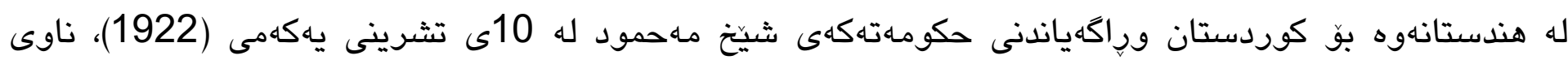

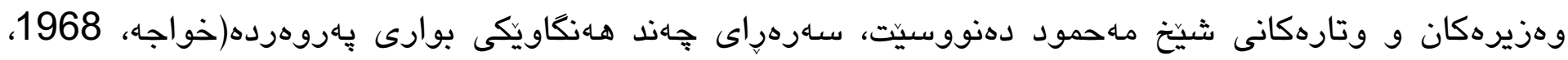

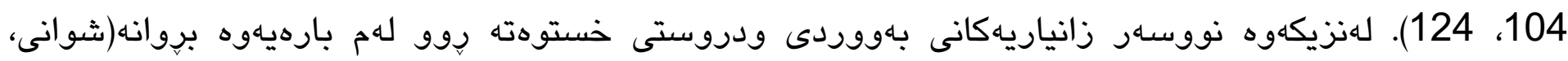
2002) (هاوار، 1991).

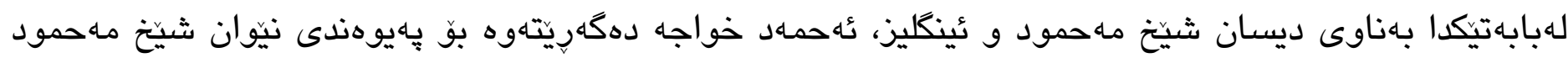
و ئينكليزهان لهدواى راكهياندنى سهربهخوّيى كوردستان له (1922)داهدواى ئهوهى له له تشرينى دووهدمى (1922)

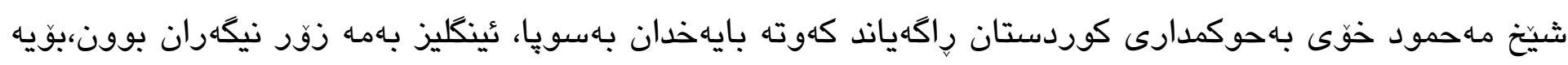

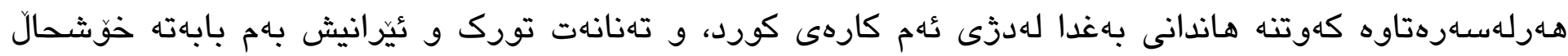

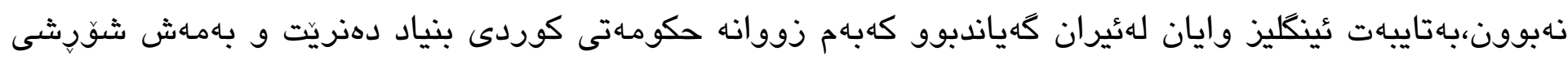

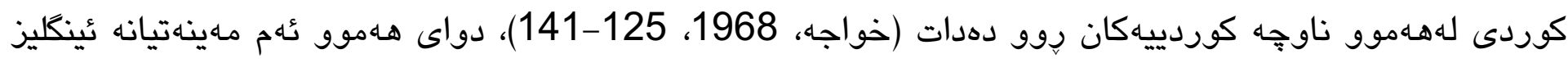

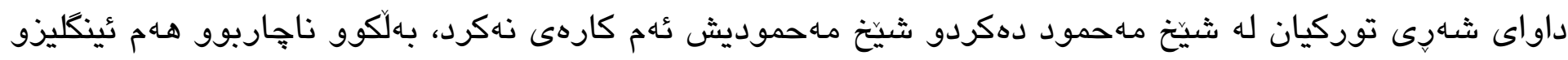

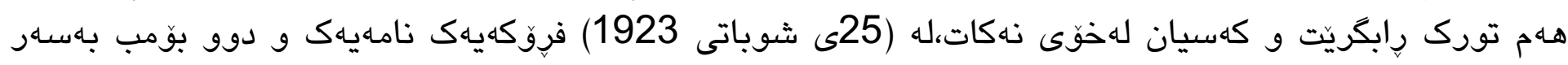

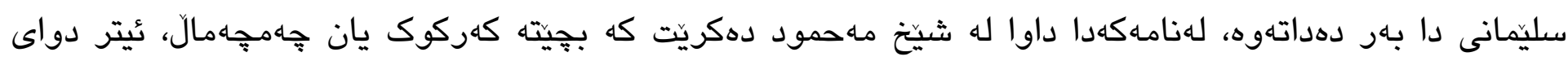

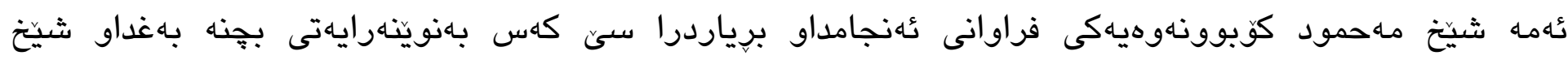

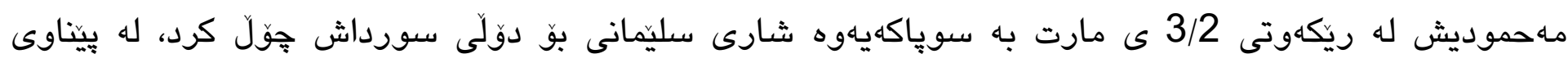

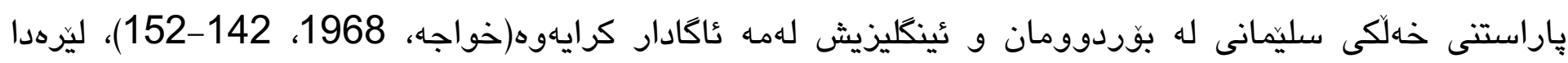

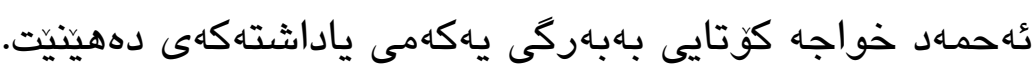

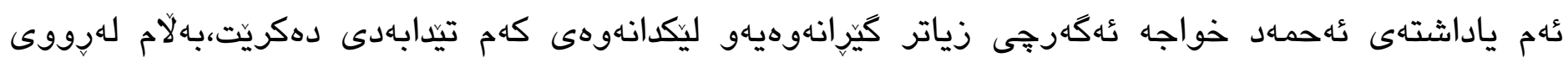

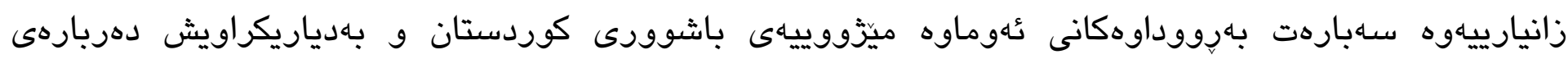

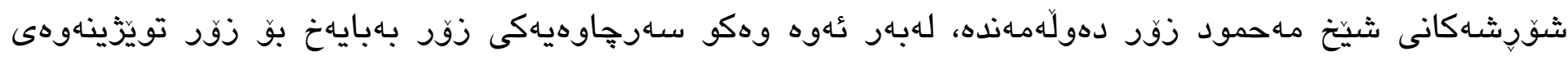

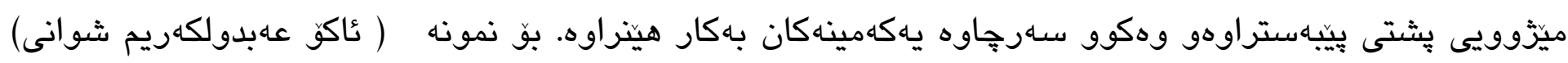

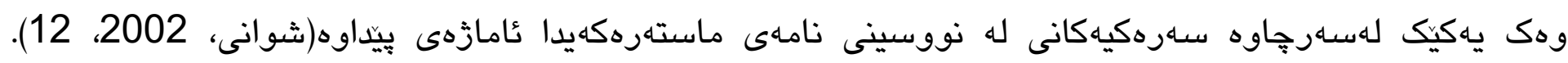

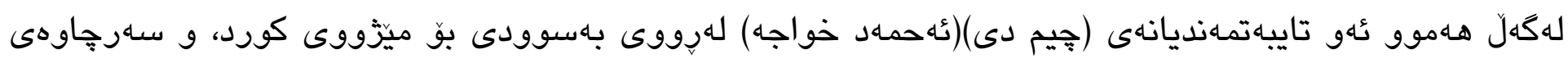

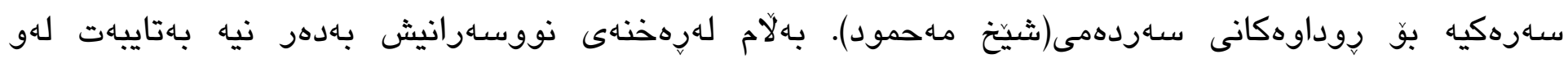




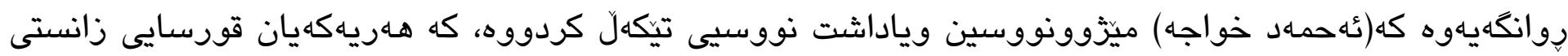

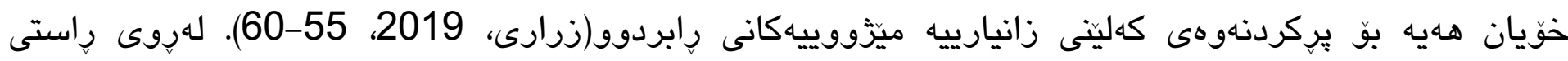

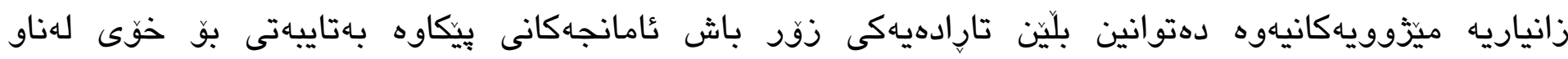

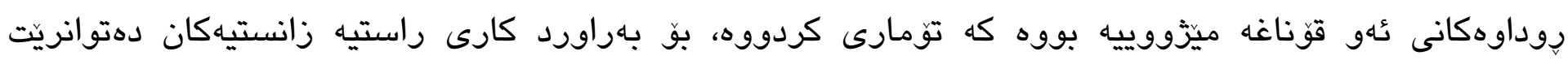

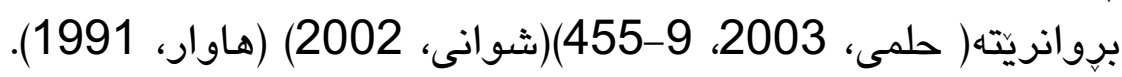

\section{ألهنجامهكاز:}

1-لهنيّوان سالآنى(1958-1968)ئهو كتيبانهى لهبووارى ميّزووييدا بهزمانى كوردى نووسراون هـموويان لهايهن

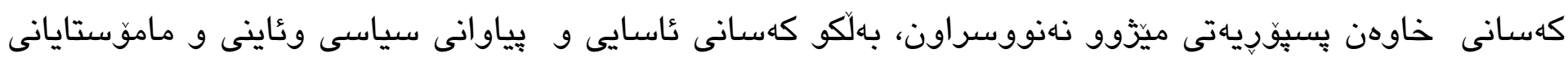
قوتابخانهان نووسيويانن.

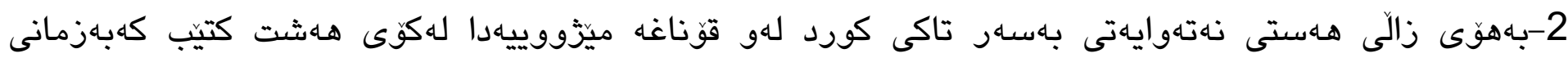

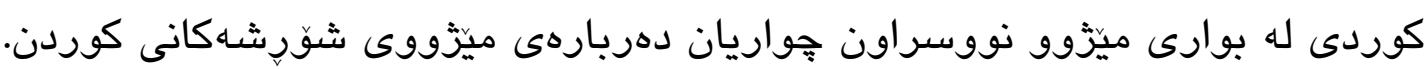

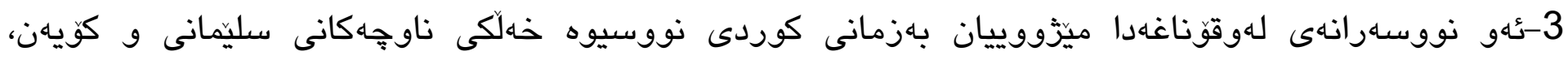
وخهلكى ناوجهاكانى ترى كوردستانيان تيدا بهاديناكريّت

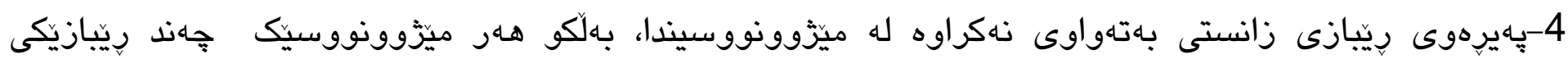

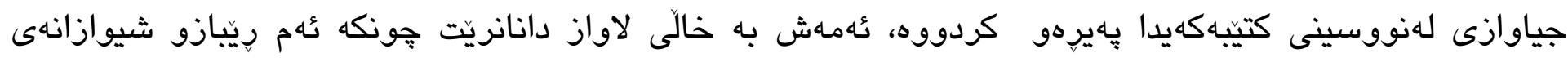

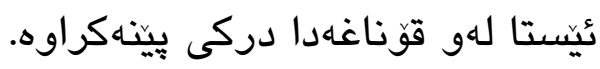

5- نووسينى تهنها (8)كتيب بهزمانى كوردى لهبووارى ميزّوونووسييدا لهماوهى (10)ده سالذا (1958-

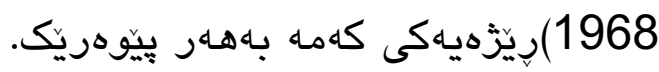




\title{
History writing by the Kurdis in Iraq (1958-1968) is among the books printed in Kurdish language.
}

\author{
Bashdar Omar Rafeeq \\ Directorate of Education Koya, Directorate General of Education of Erbil, Ministry of Education- \\ Erbil, Kurdistan Region - Iraq. \\ E-mail: bashdarumar80@gmail.com
}

\begin{abstract}
Mohammed Abdullah Kakasur
Department of History, College of Arts, University of Salahaddin - Erbil, Kurdistan Region Iraq.

E-mail: makakasur@yahoo.com
\end{abstract}

\begin{abstract}
:
The issue of writing history by Kurdish authors in Iraq between1958-1968 is analysed and explained which is about those printed books in kurdish written and published by Kurdish authors in Iraq. We have concluded that eight history books were published in Kurdish language from 1958 to 1968. Among them, seven of them were written and published from 1958 to 1962 and only one book was published in 1968. This devision of publishing those books has been due to politicial reasons and the emergence of Ailul revolution in 1961. On the one hand, it was due to the political unrest which was a stumbling block for the writing process for authors. On the other hand, however, it was due to the Aylul revolution that led to the restriction of the writing and publication processes by the Iraqi government.

The historeans were peoples of different backgrounds in Kurdistan including politicians, army, religious people, school teachers, poets, and scholars. This show the desire of writing history by peoples of different backgrounds in the Kurdish society. Regarding the academic and scientific quality and the methodology of adopted at that time in writing history books, although it cannot be compared by today's history books, but it was rather narrative and simple. In addition, very few references were usually used in writing those books. This was due to the fact that the history books authors were not historians.
\end{abstract}

Key words: History writing, history, Research Methodology, book, subject, Kurdis. 


\section{كتابة التاريخ من قبل الاكراد في العراق ( 1958-1968 ) هي من بين الكتب المببوعة باللة الكردية}

مديرية التربية كوية ، المديرية العامة التربية اربيل، وزارة التزبية، اربيل، اقليم كردستان، عيراق.

بإدار عمر رضيق

bashdarumar80@gmail.com : البريد الإلكتروني:

قسم التاريخ ، كلية الآداب ، جامعة صلاح الدين- اربيل، اقليم كردستان، عيراق.

محمد مبد الاله كاكهلسور

البريد الإكتروني: makakasur@yahoo.com

\section{ماثمص البهم:}

هذا البحث بعنوان( كتابة التاريخ من قبل الأكراد في العراق (1958-1968) هي من بين الكتب المطبوعة باللغة الكردية)يتم تحليل

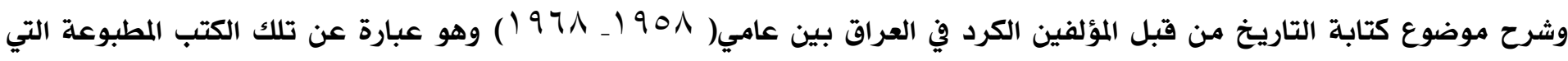

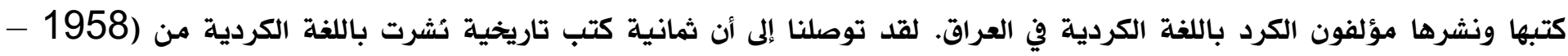
1968). من بينها سبعة كتب تم كتابتها ونشرت في الفترة ( 1958 - 1962) ونشر كتاب واحد فقط في عام( 1968) 1968). ويعود هذا الفصل في نشر هذه الكتب إلى أسباب سياسية وظهور ثورة ايلول في عام (1961). من ناحية ، كان بسبب الاضطرابات السياسية التي كانت حجر عثرة لعملية الكتابة للمؤلفين. من ناحية أخرى ، كان ذلك بسبب ثورة ايلول التي أدت إلى تقييد عمليات الكتابة والنشر من قبل الحكومة العراقية.

كان المؤرخون شعوبًا من خلفيات مختلفة في كردستان ، بما في ذلك السياسيون والعسكريون والمتدينون ومعلمو المدارس والشعراء والعلماء. هذا يظهر رغبة في كتابة التاريخ من قبل شعوب من خلفيات مختلفة في المجتمع الكردي. فيما يتعلق بالجودة الأكاديمية والعلمية والمنهجية المتبعة في ذلك الوقت في كتابة كتب التاريخ ، على الرغم من أنه لا يمكن مقارنتها بكتب التاريخ اليوم ، إلا أنها كانت روائية

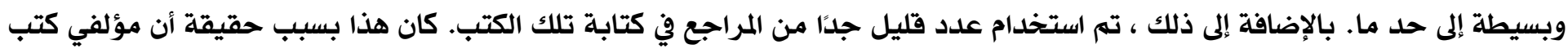
التاريخ لم يكونوا الاكاديميين والمهنيين.

الكلمات المفتاحية؛ كتابة التاريخ ، التاريخ ، منهجية البحث ، الكتاب ، الموضوع ، الأكراد. 


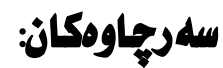

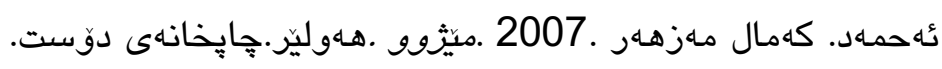

اسماعيل، زبير بيلال. 1998. ثورة بارزان 1907-1935. اربيل. مطبعة وزارة الثقافة.

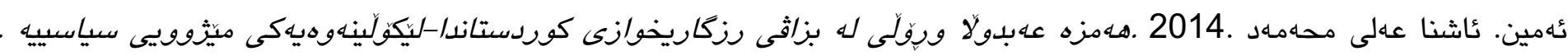

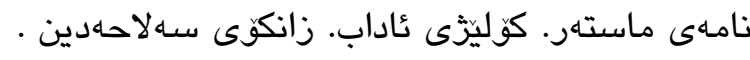
الاعظمي، صباح ياسين .2005 .علام المجمع العلمي العراقي 2004-1907 بيروت. دار العربية للموسوعات. البارزاني, مسعود. 1986. كردستان والحركة القومية الكردية- انتفاضة برزان الأولى 1931-1932. كردستان. البارزانى، مسعود. 1986. البارزانى والحركة التحريةالكردية، ثورة بارزان 1943-1945. كردستان. البارزاني, مسعود. 1987. كردستان والحركة القومية الكردية- ثورة بارزان 1945-1958. كردستان. بارزانى، مسعود. 2012. بارزانى وبزوتنهوهى بزكاريخوازى كورد 1931-1958. ب1. هـولير. البيضانى، جواد كاظم .2012,.التأريخ والمؤرخون الكرد .لبنان. دارو مكتبة البيضا.

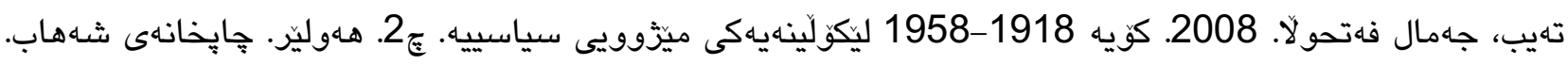
الجاف، حسن كريم. 2008. الوجيز في تأريخ ايران. ج2. اربيل. مطبعة ئاراس. 
الجبوري, حسين محمد جواد, الجانبي, قيس حاتم هاني. 2013. منهجية البحث التاريخي الأسس والمفاهيم والأساليب العلمية. عمان. دار صفاء للنشر والتوزيع. حين محرئ

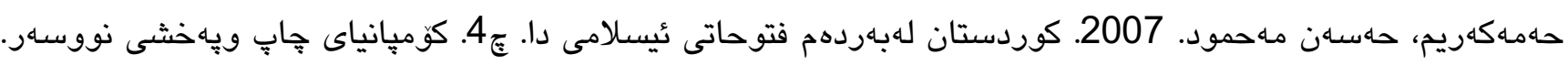
الداقوقي, أبراهيم. 2008. أكراد تركيا. ط2. أربيل. مطبعة أراس.

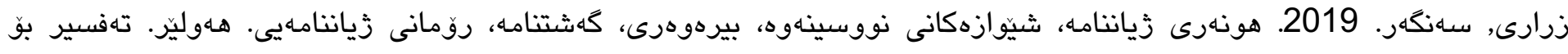
جاب وبلاوكردنهوه. زريق, قسطنطين. 1963. نحن والتاريخ. ط2 . بيروت. دار العلم للملاين.

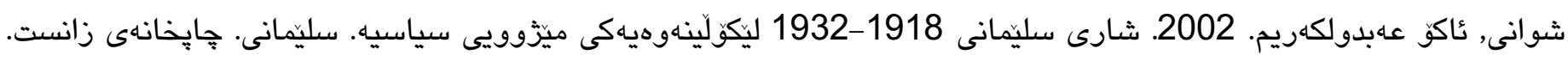
الصويركي, محمد علي .2006 ـ معجم اعلام الكرد في التاريخ الاسلامي والعصر الحليث في كردستان وخارجها .السليمانية. مطبعة حمدي.

بابان, جمال .2006, 2006 اعلام كرد العراق .السليمانية. مطبعة شثان. بابان، جمال. . 2009. اعلام الكرد ـ السليمانية. مطبعة روون. بطاطو، حنا .2005 العراق الشيوعيون والبعثيون والظبات الأحرار ـ تهران. مطبعة غدير للطباعة والنشر. حبيب ، كاظم .2005 .محات من نضال حركة التحرر الوطني للشعب الكردى في كردستان العراق .اربيلدار اراس للطباعة والنشر. حهويّزى، طاهر ئهمهد .1962.ميَزووى كويه يا كويسنجق. بهغداد. جايخانهى الوفاء. 
حسين، عبدالخالق. 2003. ثورة 14 تموز 1985 وعبدالكريم قاسم. ديمشق. دارالحصاد للنشر. حلمى، 2003. ياداشت. ع3. سليمانى. جֶايخانهى سـردهم.

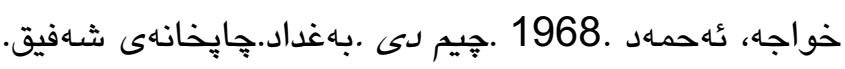
رسول، عزالدين مستةفا .1972 .حول الصحافة الكردية .بغداد. مطبعة الجاحظ. رِيِبوار، كاكهى .1960 .شقُرشى عاكرى داغ لهكورستانى توركيا .سليمانى .جايخانهى كامهران. زكى، محمد امين، 1931. خلاصة تاريخ الكرد وكردستان من أقدم العصور حتى الأن.ج1. بغداد. مطبعة دارالسلام. سجادى، دليزر علبدولا .1987 .يادى سجادى .بهاغداد.جايخانهى ئيشبيليه.

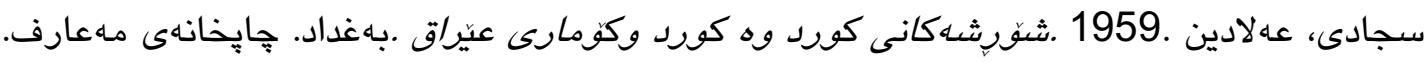
طه، عبدالواحد ذنون. 1990. اصول البحث التاريخى. الموصل. مطبعة دار الحكمه للطباعة والنشر.

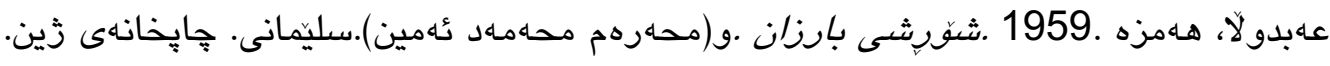
عهلائهدين، عهبدولخالق .2014 كوقيه....ناودارانى .كوردستان. بحَّناوى جايخانه. عثمان، حسن. 1965. منهج البحث التاريخي. ط2. مصر. دارالمعارف. 
عمارة, محمد. 2009. الوعي بالتاريخ وصناعة التاريخ. القاهرة. دارالسلام للطباعة والنشر.

عمر, شـاكر. 1959. تاريخ الأقوام في العراق. الأهالي(رِّذْامه). ذ(1-3).

عوزيّرى، عوسمان .1961 .شقوشعى دياربهكر .سليمانى. ذين.

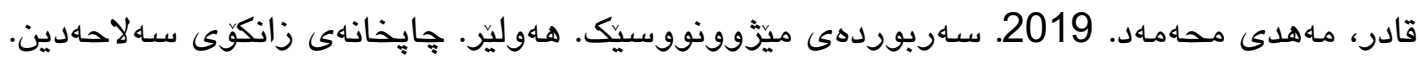

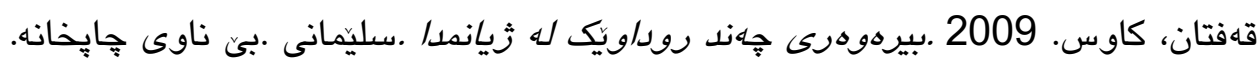

قهفتان، صالح .1959 نهتهوهى كورد توركامان نيه .سليمانى · جايخانهى كاماران.

كار، ادوارد. 1980. ماهو التاريخ. ترجمه(ماهر كيالى- بيار عقل). ط2. بيروت. مؤسسة العربية للدراسات والنشر.

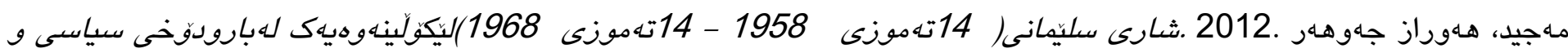

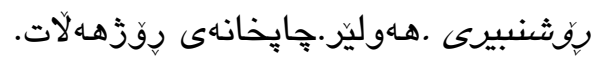

محهمهد، دليزر خالد. 2013. دور الدكتور كمال مظهر أحمد في تدوين التاريخ العراقي الحديث والمعاصر(1967-2009م). رسالة ماجستير. كلية الاداب. جامعة بيروت العربية. مـهسوم، خدر .2018 .محهمهد توفيق ووردى .كهكون(كوقار). ث(55). تشرينى يهكه. م. 2018. هاوار، محهمهد. 1991. شيخخ مههمودى قارهمان ودهولَهتهكى خواروى كوردستان. بهركى دووهم. لهندهن.

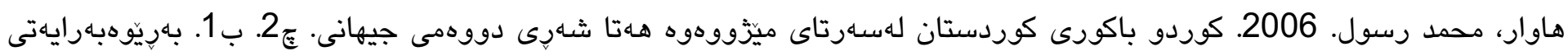

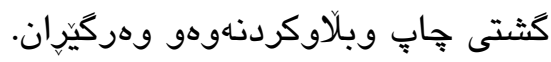




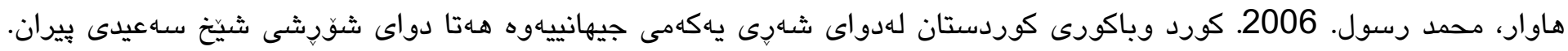

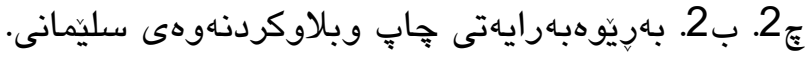

هاوار، محمد رسول. 2005. سمكو(ئيسماعيل ئاغاى شكاك)و بزوتنهوهى نهتهوايهتى كورد. ج2. سليمانى. جإِخانهى شثان. ووردى، محهمهد تؤفيق .1961 .جونى بارزانيانى قارهمان بق يهكيتى سوّقيهت .بهغداد. جايخانهى صلاح الدين. 